\title{
ASSET CYCLES AND THE RETIREMENT DECISIONS OF OLDER WORKERS
}

Jan Ondrich

CRR WP 2010-13

Date Submitted: October 2010

Date Released: October 2010

Center for Retirement Research at Boston College

Hovey House

140 Commonwealth Avenue

Chestnut Hill, MA 02467

Tel: 617-552-1762 Fax: 617-552-0191

http://crr.bc.edu/

Jan Ondrich is a professor of economics in the Department of Economics and a senior research associate at the Center for Policy Research at Syracuse University (SU). The research reported herein was pursuant to a grant from the U.S. Social Security Administration (SSA) funded as part of the Retirement Research Consortium (RRC). The findings and conclusions expressed are solely those of the authors and do not represent the views of SSA, any agency of the Federal Government, the RRC, SU, or Boston College. The author would like to thank Gary Engelhardt, James Follain, Stuart Rosenthal, Coady Wing, and Douglas Wolf for helpful discussion and both Mukta Mukherjee and Can Zhou for research assistance.

(c) 2010, by Jan Ondrich. All rights reserved. Short sections of text, not to exceed two paragraphs, may be quoted without explicit permission provided that full credit, including (C) notice, is given to the source. 


\begin{abstract}
About the Center for Retirement Research
The Center for Retirement Research at Boston College, part of a consortium that includes parallel centers at the University of Michigan and the National Bureau of Economic Research, was established in 1998 through a grant from the Social Security Administration. The Center's mission is to produce first-class research and forge a strong link between the academic community and decision makers in the public and private sectors around an issue of critical importance to the nation's future. To achieve this mission, the Center sponsors a wide variety of research projects, transmits new findings to a broad audience, trains new scholars, and broadens access to valuable data sources.
\end{abstract}

\author{
Center for Retirement Research at Boston College \\ Hovey House \\ 140 Commonwealth Avenue \\ Chestnut Hill, MA 02467 \\ phone: 617-552-1762 fax: 617-552-0191 \\ e-mail: crr@bc.edu \\ http://crr.bc.edu/
}

Affiliated Institutions:

The Brookings Institution

Massachusetts Institute of Technology

Syracuse University

Urban Institute 


\begin{abstract}
To determine how asset values of older workers affect their future retirement decisions, it is important to take into account how asset values change over asset cycles. This study uses HRS data from waves 1992 through 2008 together with restricted SSA data on geographic location to estimate a model of the age at first self-reported retirement for the subsample of married males. The model covariates include demographic variables, workplace variables, nonhousing financial wealth, housing equity and size of mortgage. The proportional hazard estimates are, for the most part, significant and of the correct sign. The estimated models replicate the decisions of the sample members for the period from 2000 to 2007. The models do not replicate the sharp drop in the aggregate retirement rate in the year 2008, the final year of the sample, which is also the first sample year in which non-housing financial wealth and housing equity both declined throughout the United States.
\end{abstract}




\section{INTRODUCTION}

An assessment of how Social Security, employer-provided pensions, individual assets, and earnings from continued employment contribute to retirement income and wealth accumulation requires an understanding of how these sources of retirement income affect the retirement decisions of older workers. ${ }^{1}$ Economists have used duration analysis to estimate the effect of the socio-economic characteristics of households on the conditional probability of retirement by household members (see, for example, Gustman and Steinmeier 1986 and 2000; Hurd 1990). However, an accurate assessment also requires an understanding both of how the levels of the various sources of retirement income have changed in the last several years.

The U.S. economy has experienced two recessions in the last decade. The first of these started in late 2000. As a result of the sharp downward pressure on profits, firms laid off millions of employees to contain costs. While employment outcomes for older workers in fact remained favorable during the recession and recovery (see Munnell, Sass, Soto and Zhivan 2006; Cooper 2008), the recession brought substantial declines in the value of their defined contribution plans and other non-housing equity assets. The S\&P 500 index fell in 2003 to a value last seen in 1997; it passed 1500 in the year 2000 but next attained that level only in 2007. The declines in retirement assets meant delays in the decision to retire (see Cooper 2008).

The recession that started in late 2007 brought with it both a decline in financial asset values and a decline in property values unprecedented in recent decades. At the beginning of April 2008, equities were off 15.5 percent from their highs in October 2007, while nationally,

\footnotetext{
${ }^{1}$ Retirement can mean Social Security claiming age, self-reported retirement, or full retirement (see Gustman and Steinmeier 2002). The econometric analysis below will be performed for a self-reported retirement definition.
} 
housing prices were down by 10 percent or more from the preceding year. Levitz (2008) provides anecdotal evidence that this double decline is delaying the retirement of older workers.

The Prentice-Gloeckler proportional hazard model (see Prentice and Gloeckler 1978;

Meyer 1990) is used to estimate the determinants of the retirement decision of married males. By including a dummy indicating the retirement status of the female spouse in the covariate list of the male spouse, the estimated model takes into account coincidence in tastes for leisure, since each spouse's utility depends on the retirement status of the other (see Hurd 1990; Gustman and Steinmeier 2000).

The proportional hazard model of time to first self-reported retirement will be estimated using all Health and Retirement Study (HRS) waves from 1992 through 2008. Demographic data and data on income, pensions, and housing and non-housing financial wealth will form the basis of the covariate list. The restricted Social Security Administration data is used to obtain the geographic location of the primary residence to aid in the construction of growth in the real value of housing.

The remainder of the paper is laid out as follows. Section 2 constitutes the literature review, while section 3 presents the estimation theory of the semiparametric proportional hazard duration model. Section 4 describes the data in greater detail. Section 5 presents the empirical results and section 6 concludes. 


\section{LITERATURE REVIEW}

Work by Diamond and Hausman (1984) is among the first important studies to examine the determinants of the retirement behavior of older men. Diamond and Hausman suggest that individual uncertainty concerning wealth accumulation, financial needs, health and job opportunities should be a central focus in using longitudinal data for this purpose. The statistical specification used by Diamond and Hausman in the first part of their study is a modification of the Weibull duration model with a Gamma random effect, introduced into the economic literature by Lancaster 1979, to control for unobserved determinants of retirement. (The modification relates to a change in the duration dependence specification for individuals turning 55.)

Diamond and Hausman argue that there are distinct advantages to using a duration model instead of other statistical methods to study retirement. First, in most longitudinal data there will be a degree of censoring (the respondent will not have retired by the end of the sample period), which can easily be incorporated into the likelihood function for duration. Second, the fact that relevant regressors are likely to change over time can be handled in a straightforward manner in a hazard analysis. Diamond and Hausman claim that the use of a continuous-time duration model avoids the time aggregation bias that comes with using discrete-time approaches. There are, however, drawbacks to using a continuous-time model of duration. First, there is a type of time aggregation that arises naturally out of the reporting intervals of many modern surveys. When this occurs, a modification to the likelihood contribution of an individual is need to retain consistency of the parameter estimates (Diamond and Hausman make the required correction). Second, with continuous-time modeling there is a tendency toward a relatively inflexible duration dependence specification compared to, say, a discrete-time probit model, in which dummy variables can be incorporated naturally for each discrete duration interval. Third, as Diamond and Hausman point 
out, it is more likely that a probit model will lead to a "formal choice model basis" or structural interpretation.

Diamond and Hausman find that both private pensions and Social Security have strong positive effects on the retirement hazard of older men. The Social Security effect is strong when benefits first become available at age 62 and rises for workers over 62 . Bad health has a significantly positive effect on the retirement hazard at all ages, no matter what financial incentives or disincentives are provided by private pensions and Social Security. Surprisingly, Diamond and Hausman find little effect for variables related to education and marital status. At least in part, this may be due to the way these variables were specified. The highest degree attained was not controlled for directly; neither was the work status of a spouse. In the latter case, a spouse who works may provide, at least until her retirement, additional financial security. Conversely, a spouse who has never worked or has previously retired (or is about to retire) may enhance the utility of retirement, since the additional leisure can be shared with a partner with similar interests. This reasoning clearly suggests a need to consider the joint retirement decision of the husband and the wife in a simultaneous framework.

Perhaps the first important work concerning the joint retirement decision of married couples is by Hurd (1990). Hurd seeks to determine whether husbands and wives tend to retire at the same time, and if so to provide an explanation for this tendency. He finds evidence of the coordination of retirement dates, both through preliminary analysis of the data as well as economic modeling. Hurd hypothesizes that the closeness of retirement dates could be due to either similarity of tastes caused by assortative mating, by economic variables, or by complementarity of leisure. He claims that each potential explanation has different implications for the response of retirement to policy changes. According to his empirical results, economic variables appear to explain very little of the closeness of retirement dates. He also rules out assortative mating as a potential explanation. The only hypothesis left is the complementarity of leisure. Unfortunately, 
Hurd feels that data limitations leave him with only a qualitative result. Hurd's methodology does not involve duration modeling.

Over the last 25 years two sets of researchers, working independently, have made significant contributions to the theory and empirical analysis of retirement behavior.

Gustman and Steinmeier focus on structural modeling and have relied primarily on the HRS for their data. Gustman and Steinmeier (1986) estimate a structural model of retirement choice that interacts lifetime preferences and incentives. Their results track actual retirement behavior closely, including peaks in the retirement rate at ages 62 and 65.

Gustman and Steinmeier (2000) develop a structural model of the joint retirement decision of married couples and estimate this model using panel data from the NLS for Mature Women. In the model utility depends on family lifetime consumption, the separate labor supply of the husband and the wife, as well as the age and health of each. The value that each spouse places on leisure is influenced by the retirement status of the other spouse. Because people who share the same tastes are more likely to marry, the retirement preferences of the husband and wife may be correlated. The husband and wife choose paths of consumption, work, and ultimate retirement that maximize their preferences over a time subject to the restriction that lifetime family consumption cannot exceed lifetime family income. As individuals age, the value of retirement eventually outweighs the value of wages, and the individuals retire.

Gustman and Steinmeier find strong evidence for the hypothesis that husbands and wives tend to retire together despite the younger ages of wives. Their estimation suggests that one reason for coordinated retirement is a coincidence of tastes for leisure. They also find that spouses generally, but husbands in particular, value retirement more if their partner has already retired. Gustman and Steinmeier's modeling of the opportunity set accounts for peaks in the 
retirement hazard of each spouse; however, they find that the co-ordination of opportunities is not responsible for the co-ordination of retirement dates.

Gustman and Steinmeier (2001) use data from the HRS to gauge respondents' knowledge about future Social Security and pension benefits by comparing respondent reports of their expected benefits with benefits calculated from Social Security earnings records and employer provided descriptions of pension plans. Their results suggest general misinformation, imprecision and lack of information about retirement benefits is the norm.

Gustman and Steinmeier (2003) construct a structural dynamic stochastic model of the way individuals make retirement and saving choices in an uncertain world and use it to analyze the effects of the stock market bubble on retirement behavior. The model includes individual variation both in retirement preferences and in time preferences. Estimates are based on information covering the period 1992 through 2000 from the HRS. The high stock market returns in the second half of the 1990s increased retirement rates for the HRS sample of workers by over 3 percentage points and would have decreased the average retirement age by about a quarter of a year if it had not been interrupted. The subsequent decline in the market neutralized the effect on retirement of the preceding stock market gains. Gustman and Steinmeier speculate in their paper that any continuing effects of the bubble after its end would probably be minimal.

More recent research by Gustman and Steinmeier (2008) addresses the topic of whether jointly modeling the retirement behavior of two-earner couples brings with it any advantages over modeling the retirement behavior of the two earners separately. Although the type of models used by Gustman and Steinmeier is different from the one that I use in this study and their focus is different from mine, their results are relevant to the present study since I model only the retirement decision of the male spouse. Gustman and Steinmeier (2008) estimate structural models of saving and retirement behavior in the face of two policies, the effects of 
which are known a priori. The findings of the study suggest that joint modeling and separate modeling give roughly the same results.

The work by David Blau primarily uses the Retirement History Survey. Blau (1994) examines movements of older men through labor force states using quarterly observations from the Retirement History Survey. He compares these transitions with those from the more typical biannual records and uncovers substantial under-counts in the biannual data. He concludes that the prevalence of labor force movements at older ages has been previously under-estimated. Blau has also studied the retirement behavior of married couples. Under the "dependent's benefits" provision of Social Security a female spouse is eligible for a spousal benefit equal to 50 percent of her husband's benefits if she chooses not to receive a retired worker benefit based on her own earnings record. Blau (1997) uses data from the Retirement History Survey to show that the spousal benefit provision has a small negative impact on labor force participation of older female spouses and a small positive impact on the labor force participation of older married men.

Blau (1998) analyzes the dynamics of the joint labor force dynamics of older couples in the United States. Using data from the Retirement History Survey, he finds strong associations between the labor force transition probabilities of one spouse and the labor force status of the other. Blau and Riphahn (1999) use monthly observations from the German Socio-Economic Panel (GSOEP) to model the labor force behavior of older married couples in Germany. They estimate a discrete-time competing-risks hazard model of transitions among labor force states that are defined by the employment status of both spouses. Their empirical results suggest, broadly speaking, that spouses are more likely to move towards states in which both are employed or in which both are not employed.

The focus of the present study is the effect of financial wealth and housing equity wealth on the retirement decision. One important study in this regard is by Case, Quigley, and Schiller (2005). Case, Quigley, and Schiller examine the links between increases in housing wealth, 
financial wealth, and consumer spending. They draw on annual data from 14 countries and quarterly state-level data from the United States to estimate regression models in levels, first differences and in error-correction form relating consumption to income and wealth measures. Case, Quigley, and Schiller find a large, statistically significant effect of housing wealth on household consumption.

Using cross-MSA variation in house-price movements in data provided by the Office of Housing Enterprise Oversight, Farnham and Sevak (2007) find evidence that changes in housing wealth affect retirement timing for a sample of older workers from the HRS. They also find evidence that housing-wealth shocks affect retirement expectations as well as present retirement rates. They estimate that a 10 -percent increase in housing wealth is associated with a reduction in expected retirement age of between three-and-a-half and five months.

Finally, two important recent studies examine the employment status and retirement expectations of older U. S. workers in the wake of the recent recession, topics which are clearly closely related to the focus of the present study. Copeland (2010) uses the March Current Population Survey to examine how employment rates of workers aged 55 and older changed over the period from 1987 to 2008. Copeland finds that the percentage of older workers working fulltime throughout the year increased steadily from 1993 to 2007 before decreasing during the recession year of 2008. Goda, Shoven, and Slavov (2010) use the HRS to investigate the relationship between stock market performance and retirement plans over the 1998 to 2008 period. The authors find a statistically significant negative relationship between the probability of working full-time at age 62 and the value of the S\&P 500 index toward the end of their study period. They do not, however, find strong evidence that changes in equity markets influence changes in retirement plans over the period as a whole. They conclude that the higher probabilities of working in recent years may be related to factors other than stock market performance, such as pessimism about economic security. 


\section{SEMIPARAMETRIC PROPORTIONAL HAZARD ESTIMATION}

In this study we focus on the determinants of the retirement behavior of married males. Specifically, I define age at retirement as the age at the first self-report of retirement for the sample of work-able married males drawn from the 1992 through 2008 waves of the HRS. A continuous work history is constructed for each sample individual starting at age 59. Each history can be stopped in five circumstances: first, after there is a self-reported retirement; second, after the last wave has been reached; third, before a non-response for the retirement question; fourth, before a wave in which the marriage has ended; and fifth, before a wave in which the male spouse is reported to be disabled. My goal is to find the determinants of the conditional retirement rate (retirement hazard rate). Some care must be taken with the statistical terminology being used. The retirement rate might be thought of as the retirement rate at a point in time within the calendar year or as the retirement rate for a given year. In most cases the meaning should be clear from the context.

A given sample in our study is assumed to consist of $N$ independent exact ages at first self-reported retirement. Let $T_{i}$ be the exact age for individuals $i=1, \ldots, N$. The exact age $T_{i}$ is properly considered to be a continuous variable. Accordingly, the point-in-time retirement hazard rate for male spouse $i$ is defined as:

$$
\lambda_{i}(t)=\lim _{\Delta t \rightarrow 0+} \operatorname{Pr}\left[t \leq T_{i}<t+\Delta t \mid T_{i} \geq t\right] / \Delta t .
$$

We assume that the point-in-time retirement hazard rate takes the proportional hazard form developed by Cox (1972):

$$
\lambda_{i}(t)=\lambda_{0}(t) \exp \left(z_{i}(t)^{\prime} \beta\right),
$$

where $\lambda_{0}(t)$ is the unknown baseline hazard at time $t, z_{i}(t)$ is the vector of time-varying covariates, and $\beta$ is the coefficient vector. 
Cox (1975) discusses a partial likelihood technique to estimate the coefficient vector. Unfortunately, partial likelihood for proportional hazards has a major problem in that the correct treatment of tied failure times is computationally burdensome. This problem is overcome in a technique developed by Prentice and Gloeckler (1978). In the Prentice-Gloeckler technique, the parameters of the log-integrated baseline hazard are non-parametrically estimated simultaneously with the coefficient vector. The estimation method does not use the continuous quality of the duration variable—it discretizes this variable into time intervals, years in the present case. Generally, when the Prentice-Gloeckler technique is used, a parameter is estimated for each interval. Parameters for intervals in which no quits occur are not estimated and all such intervals are dropped from the sample.

The conditional survivor function at exact age $t+1$ is the probability that the first selfreported retirement takes place at an exact age that is greater than or equal to $t+1$, given that it is greater than or equal to $t$ :

$$
\begin{aligned}
\operatorname{Pr}\left[T_{i}\right. & \left.\geq t+1 \mid T_{i} \geq t\right] \\
& =\exp \left(-\int_{t}^{t+1} \lambda_{i}(u) d u\right) \\
& =\exp \left(-\exp \left(z_{i}(t)^{\prime} \beta\right) \int_{t}^{t+1} \lambda_{0}(u) d u\right),
\end{aligned}
$$

where the covariate vector $z_{i}(t)$ is assumed to remain constant over the period from $t$ to $t+1$. When $t$ takes on an integer value, the period is associated with an annual interval. If we define

$$
\gamma(t)=\log \left(\int_{t}^{t+1} \lambda_{0}(u) d u\right)
$$

equation (3) can be re-written as:

$$
\operatorname{Pr}\left[T_{i} \geq t+1 \mid T_{i} \geq t\right]=\exp \left(-\exp \left(z_{i}(t)^{\prime} \beta+\gamma(t)\right)\right) .
$$

The probability that a first self-reported retirement occurs before exact age $t+1$ given that it is later than exact age $t$ is given by the complementary probability. 
The estimation strategy must take into account that some of the histories will end before a self-reported retirement for the reasons given above. These histories are said to be censored in the year that they end. Meyer (1990) takes care of this possibility by associating with each history a censoring time $C_{i}$ as well as an exact retirement age $T_{i}$. An indicator variable $\delta_{i}$ equals one if $T_{i} \leq C_{i}$, i.e., the spell is uncensored, and equals zero otherwise. For any $x$, define the function $\operatorname{int}(x)$ to be the largest integer less than or equal to $x$. Furthermore, define $k_{i}=\min \left(\operatorname{int}\left(T_{i}\right), C_{i}\right)$. Thus, if the history is uncensored, $k_{i}$ represents the start of the last sample year for the history, and if the history is censored, $k_{i}$ represents the end of the last sample year for the history.

Using these definitions, the Prentice-Gloeckler likelihood for a sample of $N$ first selfreported retirement ages can be written as

$$
\begin{aligned}
\mathscr{L}(\gamma, \beta)=\prod_{i=1}^{N} & {\left[1-\left(\exp \left\{-\exp \left(\gamma\left(k_{i}\right)+z_{i}\left(k_{i}\right)^{\prime} \beta\right)\right\}\right)\right]^{\delta_{i}} } \\
& \times \prod_{t=0}^{k_{i}-1} \exp \left\{-\exp \left(\gamma(t)+z_{i}(t)^{\prime} \beta\right)\right\} .
\end{aligned}
$$

Note that the first factor in the product in the Prentice-Gloeckler likelihood function equals one when the history is censored and in this case provides no information to the likelihood. The first factor provides information to the likelihood only when the exact retirement age is between $k_{i}$ and $k_{i}+1$. The final product in the Prentice-Gloeckler likelihood is simply the probability that the male spouse has not retired at least until time $k_{i}$. The log-likelihood function associated with the Prentice-Gloeckler likelihood is:

$$
\begin{gathered}
L(\gamma, \beta)=\sum_{i=1}^{N} \delta_{i} \log \left(1-\left(\exp \left\{-\exp \left(\gamma\left(k_{i}\right)+z_{i}\left(k_{i}\right)^{\prime} \beta\right)\right\}\right)\right) \\
-\sum_{t=0}^{k_{i}-1} \exp \left(\gamma(t)+z_{i}(t)^{\prime} \beta\right)
\end{gathered}
$$


The interpretation of parameters is an important component of presenting the results of maximum-likelihood or other non-linear estimation. The interpretation of the $\beta$ coefficients is similar to the interpretation of the regression coefficients of a log-linear or semi-log regression model. In a log-linear model, where both the dependent variable and the regressors are logged, a regression coefficient has the interpretation of an elasticity. Similarly, if a regressor is logged in the Prentice-Gloeckler likelihood, its coefficient has the interpretation of a hazard elasticity. In semi-log regression, where the dependent variable is logged but the regressors are unlogged, the elasticity of the dependent variable with respect to a regressor is given by the value of the regressor times the coefficient. Similarly, if a regressor is unlogged in a Prentice-Gloeckler likelihood, its hazard elasticity is given by the value of the regressor times the coefficient.

Interpretations of the coefficients of categorical variables remain problematic, but even these can be handled using the hazard ratio transformation of $\beta$. The hazard ratio for component $\beta_{j}$ of $\beta$ is $\exp \left(\beta_{j}\right)$. The hazard ratio is the percentage change in the hazard due to a unit increase in the $j$ th regressor. Using hazard ratios, the effect of the $j$ th regressor on the hazard is significantly positive if the hazard ratio significantly exceeds one and significantly negative if the hazard ratio is significantly less than one. Defining $s_{j}$ to be the (estimated) standard error of the maximum likelihood estimate $\hat{\beta}_{j}$ of $\beta_{j}$, the relevant asymptotic t-statistic for a test of $H_{0}: \exp \left(\beta_{j}\right)=1$ is $\left(\exp \left(\hat{\beta}_{j}\right)-1\right) /\left(\exp \left(\hat{\beta}_{j}\right) s_{j}\right)$. In many packages that estimate the PrenticeGloeckler likelihood, hazard ratios are an alternative format for the estimation results.

Future work will follow the theoretical contribution of Meyer (1990) to use random effects to incorporate unobserved heterogeneity into the Prentice-Gloeckler likelihood. The resulting likelihood is called the Prentice-Gloeckler-Meyer likelihood. The random effect summarizes the effects of all (unobserved) excluded regressors that are constant over the history 
and orthogonal to included regressors. Incorporating the multiplicative random effect $\theta_{i}$ into the hazard results in a new hazard of the form

$$
\lambda_{i}(t)=\theta_{i} \lambda_{0}(t) \exp \left(z_{i}(t)^{\prime} \beta\right)
$$

Meyer (1990) assumes that the random effects $\theta_{i}$ are independent of the $z_{i}(t)$ and are i.i.d.

Gamma variates with mean one and variance $\sigma^{2}$. Conditioning on the unobserved $\theta_{i}$ and integrating out over their (joint) distribution leads to the following log-likelihood, derived by Meyer (1990):

$$
\begin{aligned}
L\left(\gamma, \beta, \sigma^{2}\right)=\sum_{i=1}^{N} & \log \left(\left(1+\sigma^{2} \sum_{t=0}^{k_{i}-1} \exp \left\{\gamma(t)+z_{i}(t)^{\prime} \beta\right\}\right)^{-\sigma^{-2}}\right. \\
& \left.-\delta_{i}\left(1+\sigma^{2} \sum_{t=0}^{k_{i}} \exp \left\{\gamma(t)+z_{i}(t)^{\prime} \beta\right\}\right)^{-\sigma^{-2}}\right) .
\end{aligned}
$$

The variance $\sigma^{2}$ must now be estimated together with the coefficient vector $\beta$ and the $\gamma(t)$ 's. Testing the significance of the estimate of $\sigma^{2}$ is complicated by the fact that zero is on the edge of the parameter space. Under these conditions the appropriate critical value for a test of size $\alpha$ is the critical value for a test of size $2 \alpha$ under standard conditions. Finally, note that when $\theta_{i}$ equals one, the value of the hazard is the same in equations (2) and (8). This means that, conditional on the random effect assuming its mean value, the regressor coefficients and hazard ratios have the same interpretation in the Prentice-Gloeckler-Meyer likelihood as in the PrenticeGloeckler likelihood. 


\section{THE DATA}

The empirical analysis used in this study comes from the HRS, originally a longitudinal survey of a nationally representative sample of the U.S. population who were 51 to 61 years old in 1992. In 1998 the sample membership of the HRS increased in size when it was merged with the Asset and Health Dynamics among the Oldest Old (AHEAD) survey and two new special cohorts were added, the Children of the Depression Era (CODA), born in 1924-30 and War Babies (WB), born in 1942-47. It was also decided in 1998 to add new sample members every six years.

As discussed previously, a continuous work history is constructed for each sample individual starting at age 59. Each history can be stopped in five circumstances: first, after there is a self-reported retirement; second, after the last wave of the HRS has been reached; third, before a non-response for the retirement question; fourth, before a wave in which the marriage has ended; and fifth, before a wave in which the male spouse is reported to be disabled. Work histories were not constructed for the male spouse if either he or his wife was disabled before 1991, the first year for which data in the HRS is given. These restrictions on the disability-ability status of the spouse(s) were added to guarantee that a retirement decision was made freely and was not forced on the household by functional limitations. After additionally dropping a handful of work histories because of missing data that could not be filled in any reasonable way, the number of work histories that I ended up with was 2,524. These 2,524 work histories provided a total of 12,230 person-years to the present study.

The empirical retirement rates by year and age for the set of 2,524 work histories are presented in Table 1. Because the work histories of the male spouses all start at age 59, all the ages are not fully represented for a given calendar year until 2003. The spikes in the retirement rates at ages 62 and 65 discussed in the various studies by Blau and by Gustman and Steinmeier are clearly visible in the data. The remarkable feature of the data across years is the precipitous drop in retirement rates in 2008. The spike in the retirement rate at age 62, while still present in 
2008, stands at 6.58 percent, compared to a 20 percent retirement rate at age 62 in 2007. Social Security full retirement age was 65 years and 8 months in 2007 and 65 years and 10 months in 2008. Accordingly, it seems to make sense to look for a new two-year spike for the later years. In 2007 the retirement rate for 65 year-olds was 16.28 percent, but it had fallen to 2.56 percent in 2008. A similar drop occurs for 66 year-olds. In 2007 the retirement rate for 66 year-olds was 15.87 percent. This number had fallen to 8.33 percent in 2008.

The definitions of the covariates used in the empirical analysis are presented in Table 2 and their sample means and standard deviations are given in Table 3. It is possible that the sample means of some variables may vary by age. Therefore I present sample means and standard deviations for all 12,230 person-years in the first two columns of Table 3 and sample means and standard deviations at age 59 in the final two columns.

Broadly speaking, there are six types of variables used in the estimation. The first type is demographic variables. Time-invariant demographic variables are obtained from the HRS 2008 Tracker file. Time-varying demographic variables are obtained from the HRS core for the various waves. There are two race indicators, one for if the male spouse is African-American and the second for if the male spouse is non-White and non-African-American. There is an indicator for whether the male spouse has a college degree and another for whether he reports very good health. Included in the list of demographic variables are four variables that describe the female spouse. Three of them are indicator variables, one for whether the female spouse is disabled, one for whether the female spouse is retired, and one for whether the female spouse has been a nonworking homemaker. The final variable of the demographic type is meant to capture the effect of the Social Security spousal benefit on retirement behavior. The spousal benefit will be larger if the principal breadwinner, typically the male spouse, waits until the Social Security full retirement age before he retires. The effect of the Social Security spousal benefit is more likely to come into play when the female spouse is a homemaker. The final variable of the 
demographic type, then, gives the number of years to the male spouse's Social Security full retirement age when the female spouse is a homemaker. The variable is zero otherwise.

There are four workplace variables. These variables are obtained, as are all financial and housing wealth values, from the Rand HRS Data Set, Version H and the Rand HRS Income and Wealth Imputations. The first variable is the real annual log income of the female spouse, and the second is the real annual log income of the male spouse. (All deflated nominal values used in this study have been deflated by the chain-weighted GDP deflator for personal consumption expenditures (year 2005=100) constructed by the Bureau of Economic Analysis.) Although I did not feel that I could get accurate information on employment-related pension plans, I did create two indicators for the type of pension plan. The first indicator is for whether the male spouse has ever had a defined benefit plan; while the second is an indicator for whether the male spouse has not had a defined benefit plan but has had a defined contribution plan.

I construct five housing variables. The first is the log of the real home value, which is set to zero when the household does not own its own home. The second variable is the real value of home equity, real home value minus real mortgage value, in millions of dollars. To allow flexible specification for real home equity, I also create a real home-equity spline. A two-part spline with a knot at the median value of real home equity across the 12,230 person-year observations $(\$ 94,214)$ works substantially better than a three-part spline with knots at the sample tercile values of real home equity, the results for which are not presented here. The final variable is the log of the real value of the sum of mortgage and home loans.

The HRS is a biannual survey, although in a few cases it may interview households three years apart. The present work constructs annual work histories from the HRS. There is clearly the need, then, for some imputation across years. In performing this task for the final wave, because of the general collapse in home values in late 2007, care was taken not to impute values for 2007, 2008, or 2009 based on a trend for the individual household. County information from 
the restricted HRS 2009 geography data was combined with the Federal Housing Finance Agency MSA-level Repeat Sales House Price Index to do the imputations across the three years in question.

I construct seven financial wealth variables. The first variable is an indicator variable for whether the household has zero or negative non-housing financial assets. The second variable gives the log of the household's real net non-housing financial wealth when the value of the wealth is positive, and zero otherwise. The next two variables give the value and square of the value of the household's real net non-housing financial wealth in millions of dollars, given that the value of this financial wealth is positive. I also construct a real net non-housing financial wealth variable that can have positive or negative values. To allow a flexible specification for real net non-housing wealth even when it is negative, I also create a real net non-housing wealth spline. A two-part spline with a knot at the median value of real net non-housing wealth across the 12,230 person-year observations $(\$ 106,847)$ works substantially better than a three-part spline with knots at the sample tercile values, the results for which, just as for home equity, are not presented here.

As with real home values, some care must be taken with imputations for real net nonhousing financial wealth across 2007, 2008, and 2009 because of the fall in financial equity values in 2008. In performing the imputations for the final wave, care was taken not to impute values for 2007, 2008, or 2009 based on a trend for the individual household. Instead, the components of wealth for the final wave were taken from the RAND HRS Data, Version H, and values of the changes in the S\&P 500 and Barclay's Bond Index, and the levels of the threemonth Certificates of Deposit Index (CODI) were used to construct imputations across years in the final wave.

In the year 2000 Congress completely eliminated the earnings test for Social Security for workers who retire at or above the Social Security full retirement age (normal retirement age). 
By allowing these individuals to work without actuarial penalty after previously collecting Social Security, the average probability of an initial retirement at or after normal retirement age should have increased. The next variable type, the post-1999 variable type, is constructed to capture this effect and any effects of a changed economic environment after the tech bubble burst. The first of these variables is simply an indicator for whether the year is 2000 or later. The remaining variables interact the position in the macroeconomic cycle with the age group of the male spouse in that year. There are three age groups: 59 to 61, 62 to Social Security full retirement age (typically 65), and older than Social Security full retirement age. I took the 2000 recession to last from the year 2000 to the year 2002, and the following expansion to last from the year 2003 to the year 2007. There is a single year for the 2008 recession because the sample ended in the year 2008. Future work will examine specifications that simply interact the post-1999 indicator variable with the age groups.

The final type of variable is the age-indicator variable. Together the age-indicator variables allow a flexible baseline for the proportional hazard estimation. 


\section{THE RESULTS}

The hazard estimation results begin with Table 4. There are six model specifications in Table 4. As in all the tables the model specifications come in pairs. The first model in each pair contains only the post-1999 indicator, while the second model in each pair contains the full set of economic-cycle age-group interactions. The three pairs of models in Table 4 represent estimations first with only the demographic variables, second with only the workplace variables, and finally with both demographic and workplace variables.

It is clear from both the estimated coefficients and the log-likelihoods that the workplace variables are better predictors of retirement behavior than the demographic variables. Starting with the demographic variables, race does not matter for retirement behavior, but having a college degree and being in very good health both delay retirement. Male spouses retire sooner if their wives have already retired, as complementarity in tastes for leisure would imply. And finally, male spouses delay retirement to maximize the spousal benefit for a non-working wife. Moving to the workplace variables, a higher income for either spouse delays the retirement of the male spouse. The effect of having a defined benefit plan swamps the effect of having a defined contribution plan. The hazard ratio for the defined benefit plan indicator is 3.024, compared with the value of 1.747 for the defined contribution plan indicator. The variables representing the macroeconomic cycle interactions with age group have estimated coefficients that are only statistically significant when negative. Significantly negative coefficient estimates for these variables occur three out of nine times in Model 2, four of nine times in Model 4, and three out of nine times in Model 6. For each of these three models, two of the significantly negative coefficient estimates occur for the year 2008. This result works against the hypothesis of increased retirement rates for male spouses of normal retirement age in the post-1999 period. Finally, note that the spikes in the retirement at age 62 and again around ages 65 and 66 are evident in the estimations. 
In Table 5 housing variables are added to the estimations. In the first two models log home value and log mortgage are both significant and of the correct sign, although their effects are miniscule. The minuscule effect of log mortgage is also a characteristic of the rest of the table. When home equity is included linearly instead of the log of home value, the sign of the effect is incorrect for both models of the pair. Including a home-equity spline corrects this problem to some degree. The effect for the first part of the spline (below median real home value) has the correct sign and dominates the effect for the second part of the spline (above median real home value), which has an incorrect sign. A similar result is found below for the non-housing financial wealth spline. One possibility for these two results is that the very wealthy enjoy their work. Future work should investigate the effect of job satisfaction on retirement.

In Table 6 the first attempt at adding non-housing financial wealth to the estimation is presented. While the result for the zero financial assets variable always has the correct sign (poor people must continue to work), the results for every variable denoting positive non-housing financial wealth are incorrect. In Table 7 the financial assets variable works poorly, but just like the home-equity spline, the effect of the first part of the financial assets spline has the correct sign and dominates the effect of the second part of the spline. Table 8 takes home equity and log mortgage for the housing variables and takes the non-housing financial variables from Table 7. The home-equity variable in Table 8 is always statistically insignificant with the incorrect sign. The results for the financial assets variable and the financial assets spline in Table 8 are qualitatively similar to those in Table 7. Table 9 takes the home-equity spline and log mortgage as the housing variables and again takes the non-housing financial variables from Table 7. As before the effect for the first part of each spline has the correct sign and dominates the effect of the second part of the spline.

To gauge the predictive power of my estimation, I chose four preferred models: Models 3 and 4 from Table 7 and Models 3 and 4 from Table 9 (these models will be referred to as Models 
7-3, 7-4, 9-3, and 9-4, respectively, in the discussion below). Because qualitative dependent variable models will replicate generally sample averages for any class of observations if an indicator variable for the class of observations is included in the specification, some care must be taken in deciding whether the estimation predicts well. First, I attempted predictions only for the years 2000 to 2008. Model 7-4 and 9-4, which contain a reasonably extensive list of indicators for the years in question, should be expected to give reasonably accurate results.

As can be seen from Figure 1, the predicted retirement rates from Models 7-4 and 9-4 are very close to the actual retirement rates, and even come very close to the actual sample value for the year 2008. Figure 2 shows that although Models 7-3 and 9-3 do not do a bad job for the years 2000 to 2007, they predict poorly the actual retirement rate for the year 2008. In spite of this, I do not believe that it is correct to conclude that the first two models are the ones to be preferred. Instead, I feel that I should investigate the changes in the specification required to improve the predictive accuracy of the final two models.

The first step was to re-estimate the set of four preferred models using modified computations for the home value and non-housing financial wealth variables. For the estimation in Tables 4-9, a reported home value for the year 2008 is taken to be the correct value of the variable. The modified home-value variable uses the MSA-level repeat home sales index to calculate a home-value growth rate for 2008 and applies it to a predicted or actual home value for 2007. Only if such a calculation is not possible for a given observation is the reported home value for the year 2008 taken to be the correct value of the home-value variable in that year. Modifying the non-housing financial wealth variable entails replacing the reported value of nonhousing financial wealth for all the households that reported no decline in the year 2008 by a value that applies the sample mean rate of decline, over all households that reported a decline, to the predicted or actual value of non-housing financial wealth for 2007. 
The results of the re-estimation are presented in Table 10. A final modification is made for the predictions of the re-estimated models, presented in Figure 4. This modification scores the decline in the value of a splined variable by the coefficient estimate for the first part of the spline, whether or not, on the face of it, this is the correct thing to do. The results in Figure 4 show a movement in the correct direction for the 2008 prediction, even though the 2008 prediction is still very far off from the actual retirement rate. 


\section{CONCLUSIONS}

As mentioned earlier, Goda, Shoven, and Slavov (2010) find a statistically significant negative relationship between the probability of working full-time at age 62 and the S\&P 500 index toward the end of their study period. They do not, however, find strong evidence that changes in equity markets influence changes in retirement plans over the period as a whole. They conclude that the higher probabilities of working in recent years may be related to factors other than stock market performance, such as pessimism about economic security.

The present study examines the relationship between retirement itself, rather than plans for retirement, and the various forms of household wealth. My study finds that the drop in the actual retirement rate in 2008 is under-predicted by a retirement hazard model estimated on 1992-2008 data that includes the value of various forms of wealth as regressors. I would conclude, then, that the results of Goda, Shoven, and Slavov are qualitatively similar to my own. However, I would give a different explanation than do Goda, Shoven, and Slavov about the under-prediction. Rather than being due to increased pessimism about economic security, the under-prediction may be due to different valuations of gains and losses in wealth, as put forward by Kahneman and Tversky in their famous paper "Prospect Theory: An Analysis of Decision under Risk,” published in the Econometrica in 1979. In this paper Kahneman and Tversky present an alternative to expected utility theory in a descriptive model of decision-making under uncertainty that they call prospect theory. Kahneman and Tversky suggest that people underweight outcomes that are probable compared to outcomes obtained with certainty and also discard components shared by all prospects being considered. In prospect theory value is assigned to gains and losses of wealth rather than to the final total of wealth. The value function is defined on deviations from a reference point and is generally steeper for losses than for gains.

Using household wealth in 2007 as the reference point, the losses in wealth experienced by households were valued more highly than corresponding gains would have been. Therefore, 
even though the wealth position of a given household that lost wealth in 2008 may have matched the wealth position in an earlier year of a second household that had never previously lost wealth, all else equal, the utility of that wealth for the first household would be lower, and the first household would be less likely to retire.

My final modification in Figure 4, discussed earlier, is an attempt to gauge the steepness of the decline in utility. Valuing the wealth loss in 2008 at the large linear rate appropriate for gains for households with zero wealth improves the prediction only marginally. Assuming, for the moment, that the only relevant losses in wealth are those in financial wealth and housing wealth, a serious under-prediction of the decline in the retirement rate remains. The actual value of the wealth loss to the households that lost wealth would have had to have been substantially greater than the value of a corresponding gain for zero-wealth households.

I have not yet considered in this discussion that the 2008 recession may have revalued defined contribution plans (and possibly even defined benefit plans) downward. My final experiment is to re-examine the prediction of Figure 4 when the positive effect of defined benefit plans and defined contribution plans on retirement is reduced. If the (average) utility of defined benefit plans and defined contribution plans are both cut in half, Model 7-3 predicts a retirement rate of 6.55 percent in 2008, while Model 9-3 predicts a retirement rate of 6.18 percent. When all defined benefit plans and all defined contribution plans completely disappear, Model 7-3 predicts a retirement rate of 5.31 percent for 2008, while Model 9-3 predicts a retirement rate of 5.02 percent. These numbers are still 2 percent or more higher than the actual sample retirement rate. I conclude that the steep decline in the retirement rate in 2008 can only be explained by higher valuations of wealth losses by households than corresponding wealth gains. 


\section{References}

Blau, D. M. 1994.. “Labor Force Dynamics of Older Men,” Econometrica 62:117-156.

—. 1997. "Social Security and the Labor Supply of Older Married Couples,” Labour Economics 4:373-418.

— 1998. “Labor Force Dynamics of Older Married Couples,” Journal of Labor Economics 16:595-629.

Blau, D. M., and R. T. Riphahn. 1999. “Labor Force Transitions of Older Married Couples in Germany,” Labour Economics 6:229-251.

Cooper, J. C. 2008. “Jobs May Take a Smaller Hit This Time,” Business Week, April 21.

Copeland, C. 2010. “Employment Status Of Workers Ages 55 or Older, 1987-2008,” Employment Benefit Research Institute Notes 31.

Farnham, M. and P. Sevak. 2007. “Housing Wealth and Retirement Timing,” University of Michigan Retirement Research Center, Working Paper WP-2007-172.

Goda, G. S., J. B. Shoven, and S. N. Slavov. 2010. “Does Stock Market Performance Influence Retirement Expectations?” National Bureau of Economic Research, NBER Working Paper No. w16211.

Gustman, A. L., and T. L. Steinmeier. 1986. “A Structural Retirement Model,” Econometrica 54:555-584.

—. 2000. “Retirement in Dual-Career Families: A Structural Model,” Journal of Labor Economics 18:503-545.

—. 2001. “Imperfect Knowlege, Retirement and Saving,” Working Paper, Dartmouth College and Texas Tech University.

—. 2003. "Retirement and the Stock Bubble,” Working Paper, Dartmouth College and Texas Tech University.

— 2008. "How Does Modeling of Retirement Decisions at the Family Level Affect Estimates of the Impact of Social Security Policies on Retirement,” Working Paper 2008179, University of Michigan Retirement Research Center.

Hurd, M. 1990. “The Joint Retirement Decision of Husbands and Wives,” in D.A. Wise (ed.), Issues in the Economics of Aging, pp. 231-58. Chicago: University of Chicago Press.

Kahneman, D. and A. Tversky. 1979. "Prospect Theory: An Analysis of Decision under Risk,” Econometrica 47:263-292.

Levitz, J. 2008. “Americans Delay Retirement as Housing, Stocks Swoon,” Wall Street Journal, April 1.

Meyer, B. 1990. “Unemployment Insurance and Unemployment Spells,” Econometrica 58:75782. 
Munnell, A. H., S. Sass, M. Soto, and N. Zhivan. 2006. “Has the Displacement of Older Workers Increased?” Center for Retirement Research at Boston College, Working Paper WP2006-17.

Prentice, R. and L. Gloeckler. 1978. "Regression Analysis with Grouped Survival Data with Application to Breast Cancer Data,” Biometrics 34:57-67. 
Table 1.

Empirical Retirement Rates (Std Dev) by Age and Year

\begin{tabular}{|c|c|c|c|c|c|c|c|c|c|}
\hline \multicolumn{10}{|c|}{ Year } \\
\hline Age & 1991 & 1992 & 1993 & 1994 & 1995 & 1996 & 1997 & 1998 & 1999 \\
\hline 59 & $\begin{array}{c}0.0368 \\
(0.0137)\end{array}$ & $\begin{array}{c}0.0387 \\
(0.0144)\end{array}$ & $\begin{array}{c}0.0353 \\
(0.0142)\end{array}$ & $\begin{array}{c}0.0585 \\
(0.0180)\end{array}$ & $\begin{array}{c}0.0529 \\
(0.0172)\end{array}$ & $\begin{array}{c}0.0466 \\
(0.0152)\end{array}$ & $\begin{array}{c}0.0541 \\
(0.0167)\end{array}$ & $\begin{array}{c}0.0513 \\
(0.0177)\end{array}$ & $\begin{array}{c}0.0471 \\
(0.0163)\end{array}$ \\
\hline 60 & - & $\begin{array}{c}0.0734 \\
(0.0197)\end{array}$ & $\begin{array}{c}0.0397 \\
(0.0159)\end{array}$ & $\begin{array}{c}0.0566 \\
(0.0184)\end{array}$ & $\begin{array}{c}0.0576 \\
(0.0198)\end{array}$ & $\begin{array}{c}0.0497 \\
(0.0172)\end{array}$ & $\begin{array}{c}0.0446 \\
(0.0165)\end{array}$ & $\begin{array}{c}0.0651 \\
(0.0190)\end{array}$ & $\begin{array}{c}0.0534 \\
(0.0197)\end{array}$ \\
\hline 61 & . & . & $\begin{array}{c}0.0694 \\
(0.0213)\end{array}$ & $\begin{array}{c}0.0704 \\
(0.0215)\end{array}$ & $\begin{array}{c}0.0809 \\
(0.0235)\end{array}$ & $\begin{array}{c}0.0698 \\
(0.0225)\end{array}$ & $\begin{array}{c}0.0909 \\
(0.0251)\end{array}$ & $\begin{array}{c}0.1014 \\
(0.0249)\end{array}$ & $\begin{array}{c}0.0758 \\
(0.0231)\end{array}$ \\
\hline 62 & . & · & · & $\begin{array}{c}0.2239 \\
(0.0361)\end{array}$ & $\begin{array}{c}0.2479 \\
(0.0401)\end{array}$ & $\begin{array}{c}0.1707 \\
(0.0341)\end{array}$ & $\begin{array}{c}0.1981 \\
(0.0389)\end{array}$ & $\begin{array}{c}0.2773 \\
(0.0412)\end{array}$ & $\begin{array}{c}0.2266 \\
(0.0371)\end{array}$ \\
\hline 63 & . & . & . & 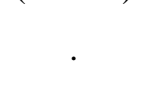 & $\begin{array}{c}0.1613 \\
(0.0383)\end{array}$ & $\begin{array}{c}0.2500 \\
(0.0464)\end{array}$ & $\begin{array}{c}0.1798 \\
(0.0409)\end{array}$ & $\begin{array}{c}0.1529 \\
(0.0393)\end{array}$ & $\begin{array}{c}0.1842 \\
(0.0448)\end{array}$ \\
\hline 64 & . & . & . & . & . & $\begin{array}{c}0.1923 \\
(0.0449)\end{array}$ & $\begin{array}{c}0.1695 \\
(0.0493)\end{array}$ & $\begin{array}{c}0.1233 \\
(0.0387)\end{array}$ & $\begin{array}{c}0.1563 \\
(0.0457)\end{array}$ \\
\hline 65 & . & . & $\cdot$ & $\cdot$ & . & $\cdot$ & $\begin{array}{c}0.2857 \\
(0.0609)\end{array}$ & $\begin{array}{c}0.2449 \\
(0.0621)\end{array}$ & $\begin{array}{c}0.3148 \\
(0.0638)\end{array}$ \\
\hline 66 & · & . & . & . & . & · & · & $\begin{array}{c}0.2750 \\
(0.0715)\end{array}$ & $\begin{array}{c}0.3030 \\
(0.0812)\end{array}$ \\
\hline 67 & . & $\cdot$ & . & $\cdot$ & $\cdot$ & . & . & (a) & $\begin{array}{c}0.0435 \\
(0.0435)\end{array}$ \\
\hline 68 & $\cdot$ & $\cdot$ & . & · & . & . & . & & \\
\hline 69 & $\cdot$ & $\cdot$ & . & . & . & . & . & . & • \\
\hline 70 & $\cdot$ & . & $\cdot$ & . & . & . & . & . & \\
\hline 71-76 & . & . & . & . & . & . & . & . & . \\
\hline
\end{tabular}


Table 1.

Empirical Retirement Rates (Std Dev) by Age and Year (cont'd)

\begin{tabular}{|c|c|c|c|c|c|c|c|c|c|}
\hline \multicolumn{10}{|c|}{ Year } \\
\hline Age & 2000 & 2001 & 2002 & 2003 & 2004 & 2005 & 2006 & 2007 & 2008 \\
\hline 59 & $\begin{array}{c}0.0389 \\
(0.0145)\end{array}$ & $\begin{array}{c}0.0000 \\
(0.0000)\end{array}$ & $\begin{array}{c}0.0104 \\
(0.0104)\end{array}$ & $\begin{array}{c}0.0500 \\
(0.0245)\end{array}$ & $\begin{array}{c}0.0260 \\
(0.0182)\end{array}$ & $\begin{array}{c}0.0313 \\
(0.0179)\end{array}$ & $\begin{array}{c}0.0370 \\
(0.0211)\end{array}$ & $\begin{array}{c}0.0222 \\
(0.0156)\end{array}$ & $\begin{array}{c}0.0154 \\
(0.0108)\end{array}$ \\
\hline 60 & $\begin{array}{c}0.0637 \\
(0.0196)\end{array}$ & $\begin{array}{c}0.0802 \\
(0.0214)\end{array}$ & $\begin{array}{c}0.0667 \\
(0.0245)\end{array}$ & $\begin{array}{c}0.0667 \\
(0.0264)\end{array}$ & $\begin{array}{c}0.0405 \\
(0.0231)\end{array}$ & $\begin{array}{c}0.0455 \\
(0.0258)\end{array}$ & $\begin{array}{c}0.0645 \\
(0.0256)\end{array}$ & $\begin{array}{c}0.0278 \\
(0.0195)\end{array}$ & $\begin{array}{c}0.0227 \\
(0.0160)\end{array}$ \\
\hline 61 & $\begin{array}{c}0.0492 \\
(0.0197)\end{array}$ & $\begin{array}{c}0.0677 \\
(0.0219)\end{array}$ & $\begin{array}{c}0.0604 \\
(0.0196)\end{array}$ & $\begin{array}{c}0.0659 \\
(0.0262)\end{array}$ & $\begin{array}{c}0.0366 \\
(0.0209)\end{array}$ & $\begin{array}{c}0.0317 \\
(0.0223)\end{array}$ & $\begin{array}{c}0.0476 \\
(0.0270)\end{array}$ & $\begin{array}{c}0.0617 \\
(0.0269)\end{array}$ & $\begin{array}{c}0.0435 \\
(0.0247)\end{array}$ \\
\hline 62 & $\begin{array}{c}0.2479 \\
(0.0394)\end{array}$ & $\begin{array}{c}0.2157 \\
(0.0409)\end{array}$ & $\begin{array}{c}0.2295 \\
(0.0382)\end{array}$ & $\begin{array}{c}0.1240 \\
(0.0291)\end{array}$ & $\begin{array}{c}0.1647 \\
(0.0405)\end{array}$ & $\begin{array}{c}0.2113 \\
(0.0488)\end{array}$ & $\begin{array}{c}0.1148 \\
(0.0411)\end{array}$ & $\begin{array}{c}0.2000 \\
(0.0544)\end{array}$ & $\begin{array}{c}0.0658 \\
(0.0286)\end{array}$ \\
\hline 63 & $\begin{array}{c}0.1515 \\
(0.0362)\end{array}$ & $\begin{array}{c}0.1646 \\
(0.0420)\end{array}$ & $\begin{array}{c}0.1519 \\
(0.0406)\end{array}$ & $\begin{array}{c}0.1310 \\
(0.0370)\end{array}$ & $\begin{array}{c}0.0796 \\
(0.0256)\end{array}$ & $\begin{array}{c}0.1875 \\
(0.0492)\end{array}$ & $\begin{array}{c}0.1667 \\
(0.0512)\end{array}$ & $\begin{array}{c}0.1569 \\
(0.0514)\end{array}$ & $\begin{array}{c}0.0000 \\
(0.0000)\end{array}$ \\
\hline 64 & $\begin{array}{c}0.0164 \\
(0.0164)\end{array}$ & $\begin{array}{c}0.2105 \\
(0.0471)\end{array}$ & $\begin{array}{c}0.1061 \\
(0.0382)\end{array}$ & $\begin{array}{c}0.1515 \\
(0.0445)\end{array}$ & $\begin{array}{c}0.0411 \\
(0.0234)\end{array}$ & $\begin{array}{c}0.1649 \\
(0.0379)\end{array}$ & $\begin{array}{c}0.0577 \\
(0.0326)\end{array}$ & $\begin{array}{c}0.1136 \\
(0.0484)\end{array}$ & $\begin{array}{c}0.0714 \\
(0.0402)\end{array}$ \\
\hline 65 & $\begin{array}{c}0.1481 \\
(0.0488)\end{array}$ & $\begin{array}{c}0.2545 \\
(0.0593)\end{array}$ & $\begin{array}{c}0.1833 \\
(0.0504)\end{array}$ & $\begin{array}{c}0.2143 \\
(0.0553)\end{array}$ & $\begin{array}{c}0.1964 \\
(0.0536)\end{array}$ & $\begin{array}{c}0.1111 \\
(0.0399)\end{array}$ & $\begin{array}{c}0.1500 \\
(0.0402)\end{array}$ & $\begin{array}{c}0.1628 \\
(0.0570)\end{array}$ & $\begin{array}{c}0.0256 \\
(0.0256)\end{array}$ \\
\hline 66 & $\begin{array}{c}0.2162 \\
(0.0686)\end{array}$ & $\begin{array}{c}0.1282 \\
(0.0542)\end{array}$ & $\begin{array}{c}0.2439 \\
(0.0679)\end{array}$ & $\begin{array}{c}0.1304 \\
(0.0502)\end{array}$ & $\begin{array}{c}0.1591 \\
(0.0558)\end{array}$ & $\begin{array}{c}0.2326 \\
(0.0652)\end{array}$ & $\begin{array}{c}0.2364 \\
(0.0578)\end{array}$ & $\begin{array}{c}0.1587 \\
(0.0464)\end{array}$ & $\begin{array}{c}0.0833 \\
(0.0467)\end{array}$ \\
\hline 67 & $\begin{array}{c}0.1739 \\
(0.0808)\end{array}$ & $\begin{array}{c}0.0741 \\
(0.0514)\end{array}$ & $\begin{array}{c}0.2059 \\
(0.0704)\end{array}$ & $\begin{array}{c}0.1333 \\
(0.0631)\end{array}$ & $\begin{array}{c}0.2000 \\
(0.0641)\end{array}$ & $\begin{array}{c}0.0000 \\
(0.0000)\end{array}$ & $\begin{array}{c}0.1818 \\
(0.0682)\end{array}$ & $\begin{array}{c}0.1316 \\
(0.0556)\end{array}$ & $\begin{array}{c}0.0189 \\
(0.0189)\end{array}$ \\
\hline 68 & $\begin{array}{c}0.1818 \\
(0.0842)\end{array}$ & $\begin{array}{c}0.1250 \\
(0.0854)\end{array}$ & $\begin{array}{c}0.0833 \\
(0.0576)\end{array}$ & $\begin{array}{c}0.0769 \\
(0.0533)\end{array}$ & $\begin{array}{c}0.1538 \\
(0.0722)\end{array}$ & $\begin{array}{c}0.1429 \\
(0.0673)\end{array}$ & $\begin{array}{c}0.0857 \\
(0.0480)\end{array}$ & $\begin{array}{c}0.0833 \\
(0.0576)\end{array}$ & $\begin{array}{c}0.0000 \\
(0.0000)\end{array}$ \\
\hline 69 & • & $\begin{array}{c}0.2353 \\
(0.1060)\end{array}$ & $\begin{array}{c}0.1429 \\
(0.0971)\end{array}$ & $\begin{array}{c}0.0500 \\
(0.0500)\end{array}$ & $\begin{array}{c}0.0417 \\
(0.0417)\end{array}$ & $\begin{array}{c}0.2381 \\
(0.0952)\end{array}$ & $\begin{array}{c}0.0833 \\
(0.0576)\end{array}$ & $\begin{array}{c}0.0333 \\
(0.0333)\end{array}$ & $\begin{array}{c}0.0455 \\
(0.0455)\end{array}$ \\
\hline 70 & - & $x^{2}-2+3$ & $\begin{array}{c}0.0769 \\
(0.0769)\end{array}$ & $\begin{array}{c}0.4167 \\
(0.1486)\end{array}$ & $\begin{array}{c}0.0000 \\
(0.0000)\end{array}$ & $\begin{array}{c}0.0476 \\
(0.0476)\end{array}$ & $\begin{array}{c}0.1250 \\
(0.0854)\end{array}$ & $\begin{array}{c}0.0500 \\
(0.0500)\end{array}$ & $\begin{array}{c}0.0000 \\
(0.0000)\end{array}$ \\
\hline 71-76 & $\cdot$ & $\cdot$ & ( & $\begin{array}{c}0.0833 \\
(0.0833)\end{array}$ & $\begin{array}{c}0.0556 \\
(0.0556)\end{array}$ & $\begin{array}{c}0.1563 \\
(0.0652)\end{array}$ & $\begin{array}{c}0.0426 \\
(0.0298)\end{array}$ & $\begin{array}{c}0.1481 \\
(0.0488)\end{array}$ & $\begin{array}{c}0.0154 \\
(0.0154)\end{array}$ \\
\hline
\end{tabular}


Table 2

Variable Definitions

\begin{tabular}{|c|c|}
\hline Variable & Definition \\
\hline \multicolumn{2}{|l|}{ Demographic Variables } \\
\hline Black & African-American indicator for male spouse (1=yes). \\
\hline Other Race & $\begin{array}{l}\text { Non-White, Non- African-American indicator for male spouse } \\
\text { (1=yes). }\end{array}$ \\
\hline College & College degree indicator for male spouse (1=yes). \\
\hline Health Very Good & Indicator for report of very good health for male spouse (1=yes). \\
\hline Spouse Disabled & Indicator for disabled female spouse (1=yes). \\
\hline Spouse Retired & Indicator for retired female spouse (1=yes). \\
\hline Spouse Homemaker & $\begin{array}{l}\text { Indicator for female spouse always non-working homemaker } \\
\text { (1=yes). }\end{array}$ \\
\hline Spouse Homemaker x Years Off & $\begin{array}{l}\text { Number of years until normal retirement age of male spouse if } \\
\text { female spouse always non-working homemaker and zero } \\
\text { otherwise. }\end{array}$ \\
\hline \multicolumn{2}{|l|}{ Workplace Variables } \\
\hline Log Spouse Income & Log of female spouse’s real annual earnings (\$) in year. \\
\hline Log Own Income & Log of male spouse’s real annual earnings (\$) in year. \\
\hline Defined Benefit Plan & $\begin{array}{l}\text { Indicator for whether male spouse has defined benefit plan } \\
\text { (1=yes). }\end{array}$ \\
\hline Defined Contribution Plan & $\begin{array}{l}\text { Indicator for whether male spouse has no defined benefit plan but } \\
\text { has defined contribution plan (1=yes). }\end{array}$ \\
\hline \multicolumn{2}{|l|}{ Housing Variables } \\
\hline Log Home Value & $\begin{array}{l}\text { Log of real home value (\$). Variable equals zero if not } \\
\text { homeowner. }\end{array}$ \\
\hline Home Equity & $\begin{array}{l}\text { Real value of home equity (\$ million).Variable equals zero if not } \\
\text { homeowner. }\end{array}$ \\
\hline Home Equity Spline Part 1 & Real value of home equity (\$ million) up to sample median value. \\
\hline Home Equity Spline Part 2 & $\begin{array}{l}\text { Real value of home equity (\$ million) in excess of sample median } \\
\text { value. }\end{array}$ \\
\hline Log Mortgage & $\begin{array}{l}\text { Log of real value of mortgage plus home loans (\$).Variable equals } \\
\text { zero if not homeowner. }\end{array}$ \\
\hline \multicolumn{2}{|l|}{ Financial Variables } \\
\hline Zero Financial Assets & $\begin{array}{l}\text { Indicator for whether household has zero or negative non-housing } \\
\text { financial wealth (1=yes). }\end{array}$ \\
\hline Log Financial Assets & $\begin{array}{l}\text { Log of household's real net non-housing financial wealth (\$), if } \\
\text { positive. }\end{array}$ \\
\hline Financial Assets $(>0)$ & $\begin{array}{l}\text { Household's real net non-housing financial wealth } \\
\text { (\$ million), if positive. }\end{array}$ \\
\hline Squared Financial Assets $(>0)$ & $\begin{array}{l}\text { If household's real net non-housing financial wealth positive, } \\
\text { square (divided by 10) of financial wealth (\$ million). }\end{array}$ \\
\hline Financial Assets & Real value of financial equity (\$ million). \\
\hline Financial Assets Spline Part 1 & $\begin{array}{l}\text { Real value of financial equity (\$ million) up to sample median } \\
\text { value. }\end{array}$ \\
\hline Financial Assets Spline Part 2 & $\begin{array}{l}\text { Real value of financial equity (\$ million) in excess of sample } \\
\text { median value. }\end{array}$ \\
\hline
\end{tabular}


Table 2

Variable Definitions

(cont'd)

\begin{tabular}{|c|c|}
\hline Variable & Definition \\
\hline \multicolumn{2}{|l|}{ Post - 1999 Variables } \\
\hline Post - 1999 Indicator & Indicator for whether the year is after 1999 (1=yes). \\
\hline 2000 Recession x Preretirement Age & $\begin{array}{l}\text { Indicator for whether the year is between } 2000 \text { and } 2002 \text { and the } \\
\text { male spouse is younger than } 62 \text { (1=yes). }\end{array}$ \\
\hline 2000 Recession x Early Retirement & $\begin{array}{l}\text { Indicator for whether the year is between } 2000 \text { and } 2002 \text { and the } \\
\text { male spouse is at least of early retirement age, but younger than } \\
\text { normal retirement age (1=yes). }\end{array}$ \\
\hline $\begin{array}{l}2000 \text { Recession x Normal } \\
\text { Retirement }\end{array}$ & $\begin{array}{l}\text { Indicator for whether the year is between } 2000 \text { and } 2002 \text { and the } \\
\text { male spouse is at least of normal retirement age (1=yes). }\end{array}$ \\
\hline Expansion x Preretirement Age & $\begin{array}{l}\text { Indicator for whether the year is between } 2003 \text { and } 2007 \text { and the } \\
\text { male spouse is younger than } 62 \text { (1=yes). }\end{array}$ \\
\hline Expansion x Early Retirement & $\begin{array}{l}\text { Indicator for whether the year is between } 2003 \text { and } 2007 \text { and the } \\
\text { male spouse is at least of early retirement age, but younger than } \\
\text { normal retirement age ( } 1=\text { yes). }\end{array}$ \\
\hline Expansion x Normal Retirement & $\begin{array}{l}\text { Indicator for whether the year is between } 2003 \text { and } 2007 \text { and the } \\
\text { male spouse is at least of normal retirement age (1=yes). }\end{array}$ \\
\hline 2008 Recession x Preretirement Age & $\begin{array}{l}\text { Indicator for whether the year is } 2008 \text { and the male spouse is } \\
\text { younger than } 62 \text { (1=yes). }\end{array}$ \\
\hline 2008 Recession x Early Retirement & $\begin{array}{l}\text { Indicator for whether the year is } 2008 \text { and the male spouse is at } \\
\text { least of early retirement age, but younger than normal retirement } \\
\text { age (1=yes). }\end{array}$ \\
\hline $\begin{array}{l}2008 \text { Recession x Normal } \\
\text { Retirement }\end{array}$ & $\begin{array}{l}\text { Indicator for whether the year is } 2008 \text { and the male spouse is at } \\
\text { least of normal retirement age (1=yes). }\end{array}$ \\
\hline \multicolumn{2}{|l|}{ Age Indicators } \\
\hline Age $x x$ & $\begin{array}{l}\text { Indicator for whether male spouse is age } x x \text { in year (1=yes). The } \\
\text { values for } x x \text { run from } 59 \text { through to } 70 .\end{array}$ \\
\hline Age 71-76 & $\begin{array}{l}\text { Indicator for whether male spouse is between the ages of } 71 \text { and } 76 \\
\text { in year (1=yes). }\end{array}$ \\
\hline
\end{tabular}


Table 3. Variable Means

\begin{tabular}{|c|c|c|c|c|}
\hline \multirow[b]{2}{*}{ Variable } & \multicolumn{2}{|c|}{ All Years } & \multicolumn{2}{|c|}{ First Year } \\
\hline & Mean & Std Dev & Mean & Std Dev \\
\hline \multicolumn{5}{|l|}{ Demographic Variables } \\
\hline Black & 0.0962 & 0.2948 & 0.1066 & 0.3086 \\
\hline Other Race & 0.0310 & 0.1733 & 0.0333 & 0.1794 \\
\hline College & 0.2901 & 0.4538 & 0.2670 & 0.4425 \\
\hline Health Very Good & 0.5166 & 0.4997 & 0.5254 & 0.4995 \\
\hline Spouse Disabled & 0.0669 & 0.2498 & 0.0574 & 0.2327 \\
\hline Spouse Retired & 0.1064 & 0.3083 & 0.0357 & 0.1855 \\
\hline Spouse Homemaker & 0.2524 & 0.4344 & 0.2445 & 0.4298 \\
\hline Spouse Homemaker x Years Off & 0.3226 & 1.3369 & 0.8645 & 2.2624 \\
\hline \multicolumn{5}{|l|}{ Workplace Variables } \\
\hline Log Spouse Income & 5.9821 & 4.8726 & 6.7071 & 4.6827 \\
\hline Log Own Income & 8.6743 & 4.0723 & 9.2141 & 3.6452 \\
\hline Defined Benefit Plan & 0.2353 & 0.4242 & 0.2698 & 0.4439 \\
\hline Defined Contribution Plan & 0.3963 & 0.4892 & 0.3130 & 0.4638 \\
\hline \multicolumn{5}{|l|}{ Housing Variables } \\
\hline Log Home Value & 10.9624 & 3.2748 & 10.7985 & 3.3761 \\
\hline Home Equity & 0.1509 & 0.4221 & 0.1215 & 0.2605 \\
\hline Home Equity Spline Part 1 & 0.0678 & 0.0362 & 0.0647 & 0.0372 \\
\hline Home Equity Spline Part 2 & 0.0831 & 0.4153 & 0.0568 & 0.2512 \\
\hline Log Mortgage & 6.4208 & 5.3469 & 6.6454 & 5.3070 \\
\hline \multicolumn{5}{|l|}{ Financial Variables } \\
\hline Zero Financial Assets & 0.0432 & 0.2033 & 0.0479 & 0.2137 \\
\hline Log Financial Assets & 11.0349 & 2.9420 & 10.7661 & 2.9925 \\
\hline Financial Assets $(>0)$ & 0.4232 & 2.0897 & 0.2933 & 0.8126 \\
\hline Squared Financial Assets $(>0)$ & 0.4545 & 14.4357 & 0.0746 & 0.9030 \\
\hline Financial Assets & 0.4226 & 2.0897 & 0.2925 & 0.8129 \\
\hline Financial Assets Spline Part 1 & 0.0704 & 0.0437 & 0.0663 & 0.0443 \\
\hline Financial Assets Spline Part 2 & 0.3522 & 2.0831 & 0.2262 & 0.8003 \\
\hline \multicolumn{5}{|l|}{ Post 1999 Variables } \\
\hline Post - 1999 Indicator & 0.5519 & 0.4973 & 0.3716 & 0.4833 \\
\hline 2000 Recession x Preretirement Age & 0.0991 & 0.2988 & 0.1521 & 0.3592 \\
\hline 2000 Recession x Early Retirement & 0.0658 & 0.2480 & 0 & 0 \\
\hline 2000 Recession x Normal Retirement & 0.0881 & 0.2834 & 0 & 0 \\
\hline Expansion x Preretirement Age & 0.0980 & 0.2974 & 0.1680 & 0.3739 \\
\hline Expansion x Early Retirement & 0.1040 & 0.3053 & 0 & 0 \\
\hline Expansion x Normal Retirement & 0.1119 & 0.3152 & 0 & 0 \\
\hline 2008 Recession x Preretirement Age & 0.0235 & 0.1514 & 0.0515 & 0.2211 \\
\hline 2008 Recession x Early Retirement & 0.0164 & 0.1268 & 0 & 0 \\
\hline 2008 Recession x Normal Retirement & 0.0141 & 0.1181 & 0 & 0 \\
\hline \multicolumn{5}{|l|}{ Age Indicators } \\
\hline Age 59 & 0.2064 & 0.4047 & 1.0000 & 0 \\
\hline Age 60 & 0.1759 & 0.3807 & 0 & 0 \\
\hline Age 61 & 0.1485 & 0.3556 & 0 & 0 \\
\hline Age 62 & 0.1267 & 0.3326 & 0 & 0 \\
\hline Age 63 & 0.0897 & 0.2858 & 0 & 0 \\
\hline Age 64 & 0.0696 & 0.2545 & 0 & 0 \\
\hline Age 65 & 0.0544 & 0.2268 & 0 & 0 \\
\hline Age 66 & 0.0390 & 0.1936 & 0 & 0 \\
\hline Age 67 & 0.0275 & 0.1635 & 0 & 0 \\
\hline Age 68 & 0.0191 & 0.1370 & 0 & 0 \\
\hline Age 69 & 0.0141 & 0.1178 & 0 & 0 \\
\hline Age 70 & 0.0106 & 0.1026 & 0 & 0 \\
\hline Age 71-76 & 0.0186 & 0.1353 & 0 & 0 \\
\hline
\end{tabular}


Table 4.

Complementary Log-Log Regression

Demographic and Workplace Variables

\begin{tabular}{|c|c|c|c|c|c|c|}
\hline Variable & Model 1 & Model 2 & Model 3 & Model 4 & Model 5 & Model 6 \\
\hline \multicolumn{7}{|l|}{ Demographic Variables } \\
\hline Black & $\begin{array}{l}-0.0413 \\
(0.0964)\end{array}$ & $\begin{array}{l}-0.0443 \\
(0.0964)\end{array}$ & & & $\begin{array}{l}-0.0664 \\
(0.0966)\end{array}$ & $\begin{array}{l}-0.0693 \\
(0.0966)\end{array}$ \\
\hline Other Race & $\begin{array}{l}-0.0894 \\
(0.1745)\end{array}$ & $\begin{array}{l}-0.0753 \\
(0.1743)\end{array}$ & & & $\begin{array}{l}-0.0380 \\
(0.1749)\end{array}$ & $\begin{array}{l}-0.0294 \\
(0.1750)\end{array}$ \\
\hline College & $\begin{array}{l}-0.3183 \\
(0.0689)\end{array}$ & $\begin{array}{l}-0.3141 \\
(0.0691)\end{array}$ & & & $\begin{array}{l}-0.3745 \\
(0.0694)\end{array}$ & $\begin{array}{l}-0.3653 \\
(0.0695)\end{array}$ \\
\hline Health Very Good & $\begin{array}{l}-0.1132 \\
(0.0576)\end{array}$ & $\begin{array}{l}-0.1225 \\
(0.0576)\end{array}$ & & & $\begin{array}{l}-0.1536 \\
(0.0577)\end{array}$ & $\begin{array}{l}-0.1673 \\
(0.0577)\end{array}$ \\
\hline Spouse Disabled & $\begin{array}{c}0.1576 \\
(0.1028)\end{array}$ & $\begin{array}{c}0.1723 \\
(0.1030)\end{array}$ & & & $\begin{array}{c}0.0828 \\
(0.1051)\end{array}$ & $\begin{array}{c}0.0956 \\
(0.1054)\end{array}$ \\
\hline Spouse Retired & $\begin{array}{c}0.3420 \\
(0.0814)\end{array}$ & $\begin{array}{c}0.3361 \\
(0.0815)\end{array}$ & & & $\begin{array}{c}0.1355 \\
(0.0911)\end{array}$ & $\begin{array}{c}0.1287 \\
(0.0913)\end{array}$ \\
\hline Spouse Homemaker & $\begin{array}{l}-0.0221 \\
(0.0699)\end{array}$ & $\begin{array}{l}-0.0250 \\
(0.0704)\end{array}$ & & & $\begin{array}{l}-0.1869 \\
(0.0818)\end{array}$ & $\begin{array}{l}-0.1892 \\
(0.0823)\end{array}$ \\
\hline $\begin{array}{l}\text { Spouse Homemaker x } \\
\text { Years Off }\end{array}$ & $\begin{array}{l}-0.0736 \\
(0.0377)\end{array}$ & $\begin{array}{l}-0.0620 \\
(0.0411)\end{array}$ & & & $\begin{array}{l}-0.0761 \\
(0.0379)\end{array}$ & $\begin{array}{l}-0.0657 \\
(0.0409)\end{array}$ \\
\hline \multicolumn{7}{|l|}{ Workplace Variables } \\
\hline Log Spouse Income & & & $\begin{array}{c}-0.0254 \\
(0.00578)\end{array}$ & $\begin{array}{c}-0.0258 \\
(0.00578)\end{array}$ & $\begin{array}{c}-0.0292 \\
(0.00735)\end{array}$ & $\begin{array}{c}-0.0294 \\
(0.00737)\end{array}$ \\
\hline Log Own Income & & & $\begin{array}{c}-0.0657 \\
(0.00710)\end{array}$ & $\begin{array}{c}-0.0644 \\
(0.00711)\end{array}$ & $\begin{array}{c}-0.0667 \\
(0.00717)\end{array}$ & $\begin{array}{c}-0.0652 \\
(0.00717)\end{array}$ \\
\hline Defined Benefit Plan & & & $\begin{array}{l}1.1066 \\
(0.0816)\end{array}$ & $\begin{array}{c}1.0961 \\
(0.0814)\end{array}$ & $\begin{array}{c}1.1422 \\
(0.0822)\end{array}$ & $\begin{array}{c}1.1328 \\
(0.0820)\end{array}$ \\
\hline Defined Contribution Plan & & & $\begin{array}{c}0.5577 \\
(0.0782)\end{array}$ & $\begin{array}{c}0.5396 \\
(0.0781)\end{array}$ & $\begin{array}{c}0.5962 \\
(0.0787)\end{array}$ & $\begin{array}{c}0.5781 \\
(0.0785)\end{array}$ \\
\hline \multicolumn{7}{|l|}{ Post - 1999 Variables } \\
\hline Post - 1999 Indicator & $\begin{array}{l}-0.3184 \\
(0.0617)\end{array}$ & & $\begin{array}{l}-0.3314 \\
(0.0614)\end{array}$ & & $\begin{array}{l}-0.3156 \\
(0.0618)\end{array}$ & \\
\hline 2000 Recession $x$ & & -0.1735 & & -0.1718 & & -0.1524 \\
\hline Preretirement Age & & $(0.1444)$ & & $(0.1441)$ & & $(0.1445)$ \\
\hline 2000 Recession x Early & & -0.1177 & & -0.1336 & & -0.1466 \\
\hline Retirement & & $(0.1010)$ & & $(0.1013)$ & & $(0.1014)$ \\
\hline 2000 Recession x Normal & & 0.0131 & & 0.00858 & & 0.0284 \\
\hline Retirement & & $(0.1260)$ & & $(0.1268)$ & & $(0.1271)$ \\
\hline Expansion x Preretirement & & -0.2847 & & -0.3237 & & -0.2811 \\
\hline Age & & $(0.1537)$ & & $(0.1530)$ & & $(0.1536)$ \\
\hline Expansion x Early & & -0.4538 & & -0.4455 & & -0.4468 \\
\hline Retirement & & $(0.0946)$ & & $(0.0946)$ & & $(0.0949)$ \\
\hline Expansion x Normal & & 0.1052 & & 0.0947 & & 0.1033 \\
\hline Retirement & & $(0.1574)$ & & $(0.1575)$ & & $(0.1575)$ \\
\hline 2008 Recession $\mathrm{x}$ & & -0.5794 & & -0.8333 & & -0.5445 \\
\hline Preretirement Age & & $(0.4144)$ & & $(0.3843)$ & & $(0.4123)$ \\
\hline 2008 Recession x Early & & -1.6017 & & -1.5878 & & -1.5901 \\
\hline Retirement & & $(0.3375)$ & & $(0.3379)$ & & $(0.3377)$ \\
\hline 2008 Recession x Normal & & -1.4671 & & -1.4750 & & -1.4441 \\
\hline Retirement & & $(0.4835)$ & & $(0.4845)$ & & $(0.4849)$ \\
\hline
\end{tabular}


Table 4.

Complementary Log-Log Regression

Demographic and Workplace Variables

(cont'd)

\begin{tabular}{lcccccc}
\hline Variable & Model 1 & Model 2 & Model 3 & Model 4 & Model 5 & Model 6 \\
\hline Age Indicators & & & & & & \\
Age 59 & -2.9566 & -2.9765 & -2.9108 & -2.9177 & -2.6549 & -2.6786 \\
& $(0.1104)$ & $(0.1138)$ & $(0.1232)$ & $(0.1269)$ & $(0.1367)$ & $(0.1395)$ \\
Age 60 & -2.5877 & -2.6121 & -2.5386 & -2.5540 & -2.3062 & -2.3351 \\
& $(0.1014)$ & $(0.1068)$ & $(0.1155)$ & $(0.1209)$ & $(0.1288)$ & $(0.1333)$ \\
Age 61 & -2.4049 & -2.4310 & -2.3450 & -2.3638 & -2.1301 & -2.1609 \\
& $(0.1014)$ & $(0.1087)$ & $(0.1139)$ & $(0.1206)$ & $(0.1273)$ & $(0.1333)$ \\
Age 62 & -1.2327 & -1.2113 & -1.1781 & -1.1622 & -0.9722 & -0.9461 \\
& $(0.0749)$ & $(0.0782)$ & $(0.0901)$ & $(0.0927)$ & $(0.1066)$ & $(0.1092)$ \\
Age 63 & -1.5044 & -1.4818 & -1.4585 & -1.4412 & -1.2520 & -1.2208 \\
& $(0.0932)$ & $(0.0966)$ & $(0.1048)$ & $(0.1076)$ & $(0.1195)$ & $(0.1222)$ \\
Age 64 & -1.7010 & -1.6671 & -1.6456 & -1.6201 & -1.4449 & -1.4039 \\
Age 65 & $(0.1114)$ & $(0.1150)$ & $(0.1203)$ & $(0.1235)$ & $(0.1338)$ & $(0.1369)$ \\
& -1.2228 & -1.3172 & -1.1835 & -1.2908 & -0.9884 & -1.0875 \\
Age 66 & $(0.1070)$ & $(0.1136)$ & $(0.1153)$ & $(0.1226)$ & $(0.1289)$ & $(0.1354)$ \\
Age 67 & -1.1868 & -1.4791 & -1.1593 & -1.4492 & -0.9593 & -1.2524 \\
& $(0.1236)$ & $(0.1825)$ & $(0.1290)$ & $(0.1865)$ & $(0.1427)$ & $(0.1961)$ \\
Age 68 & -1.7692 & -2.0126 & -1.7192 & -1.9729 & -1.5329 & -1.7788 \\
Age 69 & $(0.1785)$ & $(0.2353)$ & $(0.1812)$ & $(0.2390)$ & $(0.1919)$ & $(0.2467)$ \\
& -1.8912 & -2.1976 & -1.8678 & -2.1536 & -1.6747 & -1.9708 \\
Age 70 & $(0.2228)$ & $(0.2819)$ & $(0.2243)$ & $(0.2849)$ & $(0.2331)$ & $(0.2918)$ \\
Age 71-76 & -1.8845 & -2.1982 & -1.8357 & -2.1618 & -1.6393 & -1.9656 \\
& $(0.2555)$ & $(0.3125)$ & $(0.2545)$ & $(0.3133)$ & $(0.2627)$ & $(0.3199)$ \\
Log Likelihood & -2.1412 & -2.3724 & -2.0857 & -2.3259 & -1.8875 & -2.1363 \\
& $(0.3265)$ & $(0.3799)$ & $(0.3264)$ & $(0.3807)$ & $(0.3331)$ & $(0.3860)$ \\
& -2.1621 & -2.5646 & -2.0998 & -2.5030 & -1.9129 & -2.3218 \\
& $(0.2503)$ & $(0.2988)$ & $(0.2485)$ & $(0.2980)$ & $(0.2587)$ & $(0.3062)$ \\
\hline
\end{tabular}


Table 5.

Complementary Log-Log Regression Housing Variables

\begin{tabular}{|c|c|c|c|c|c|c|}
\hline Variable & Model 1 & Model 2 & Model 3 & Model 4 & Model 5 & Model 6 \\
\hline \multicolumn{7}{|l|}{ Demographic Variables } \\
\hline Black & $\begin{array}{l}-0.0442 \\
(0.0974)\end{array}$ & $\begin{array}{l}-0.0476 \\
(0.0973)\end{array}$ & $\begin{array}{l}-0.0927 \\
(0.0971)\end{array}$ & $\begin{array}{l}-0.0920 \\
(0.0970)\end{array}$ & $\begin{array}{l}-0.0412 \\
(0.0983)\end{array}$ & $\begin{array}{l}-0.0432 \\
(0.0983)\end{array}$ \\
\hline Other Race & $\begin{array}{c}0.0311 \\
(0.1766)\end{array}$ & $\begin{array}{c}0.0431 \\
(0.1767)\end{array}$ & $\begin{array}{l}-0.0710 \\
(0.1753)\end{array}$ & $\begin{array}{l}-0.0564 \\
(0.1754)\end{array}$ & $\begin{array}{l}-0.0104 \\
(0.1759)\end{array}$ & $\begin{array}{l}0.00438 \\
(0.1759)\end{array}$ \\
\hline College & $\begin{array}{l}-0.3682 \\
(0.0699)\end{array}$ & $\begin{array}{l}-0.3590 \\
(0.0701)\end{array}$ & $\begin{array}{l}-0.3261 \\
(0.0710)\end{array}$ & $\begin{array}{l}-0.3222 \\
(0.0710)\end{array}$ & $\begin{array}{l}-0.3306 \\
(0.0710)\end{array}$ & $\begin{array}{l}-0.3272 \\
(0.0711)\end{array}$ \\
\hline Health Very Good & $\begin{array}{l}-0.1502 \\
(0.0580)\end{array}$ & $\begin{array}{l}-0.1643 \\
(0.0581)\end{array}$ & $\begin{array}{l}-0.1276 \\
(0.0581)\end{array}$ & $\begin{array}{l}-0.1429 \\
(0.0582)\end{array}$ & $\begin{array}{l}-0.1427 \\
(0.0583)\end{array}$ & $\begin{array}{l}-0.1576 \\
(0.0584)\end{array}$ \\
\hline Spouse Disabled & $\begin{array}{c}0.0966 \\
(0.1054)\end{array}$ & $\begin{array}{c}0.1079 \\
(0.1057)\end{array}$ & $\begin{array}{c}0.0796 \\
(0.1053)\end{array}$ & $\begin{array}{c}0.0928 \\
(0.1055)\end{array}$ & $\begin{array}{c}0.0882 \\
(0.1055)\end{array}$ & $\begin{array}{c}0.1005 \\
(0.1058)\end{array}$ \\
\hline Spouse Retired & $\begin{array}{c}0.1146 \\
(0.0915)\end{array}$ & $\begin{array}{c}0.1103 \\
(0.0917)\end{array}$ & $\begin{array}{c}0.1318 \\
(0.0911)\end{array}$ & $\begin{array}{c}0.1246 \\
(0.0913)\end{array}$ & $\begin{array}{c}0.1138 \\
(0.0913)\end{array}$ & $\begin{array}{c}0.1085 \\
(0.0915)\end{array}$ \\
\hline Spouse Homemaker & $\begin{array}{l}-0.2004 \\
(0.0821)\end{array}$ & $\begin{array}{l}-0.2021 \\
(0.0826)\end{array}$ & $\begin{array}{l}-0.1918 \\
(0.0818)\end{array}$ & $\begin{array}{l}-0.1935 \\
(0.0823)\end{array}$ & $\begin{array}{l}-0.1931 \\
(0.0820)\end{array}$ & $\begin{array}{l}-0.1937 \\
(0.0825)\end{array}$ \\
\hline $\begin{array}{l}\text { Spouse Homemaker x } \\
\text { Years Off }\end{array}$ & $\begin{array}{l}-0.0737 \\
(0.0379)\end{array}$ & $\begin{array}{l}-0.0634 \\
(0.0410)\end{array}$ & $\begin{array}{l}-0.0786 \\
(0.0380)\end{array}$ & $\begin{array}{l}-0.0689 \\
(0.0410)\end{array}$ & $\begin{array}{l}-0.0734 \\
(0.0379)\end{array}$ & $\begin{array}{l}-0.0631 \\
(0.0410)\end{array}$ \\
\hline \multicolumn{7}{|l|}{ Workplace Variables } \\
\hline Log Spouse Income & $\begin{array}{l}-0.0266 \\
(0.00742)\end{array}$ & $\begin{array}{c}-0.0269 \\
(0.00744)\end{array}$ & $\begin{array}{c}-0.0278 \\
(0.00740)\end{array}$ & $\begin{array}{l}-0.0281 \\
(0.00741)\end{array}$ & $\begin{array}{l}-0.0282 \\
(0.00741)\end{array}$ & $\begin{array}{c}-0.0283 \\
(0.00743)\end{array}$ \\
\hline Log Own Income & $\begin{array}{c}-0.0653 \\
(0.00718)\end{array}$ & $\begin{array}{c}-0.0637 \\
(0.00719)\end{array}$ & $\begin{array}{c}-0.0668 \\
(0.00720)\end{array}$ & $\begin{array}{c}-0.0652 \\
(0.00720)\end{array}$ & $\begin{array}{c}-0.0665 \\
(0.00720)\end{array}$ & $\begin{array}{c}-0.0647 \\
(0.00721)\end{array}$ \\
\hline Defined Benefit Plan & $\begin{array}{c}1.1244 \\
(0.0823)\end{array}$ & $\begin{array}{l}1.1153 \\
(0.0821)\end{array}$ & $\begin{array}{l}1.1308 \\
(0.0821)\end{array}$ & $\begin{array}{c}1.1222 \\
(0.0820)\end{array}$ & $\begin{array}{c}1.1125 \\
(0.0824)\end{array}$ & $\begin{array}{c}1.1051 \\
(0.0823)\end{array}$ \\
\hline Defined Contribution Plan & $\begin{array}{c}0.5773 \\
(0.0788)\end{array}$ & $\begin{array}{c}0.5600 \\
(0.0786)\end{array}$ & $\begin{array}{c}0.5913 \\
(0.0786)\end{array}$ & $\begin{array}{c}0.5732 \\
(0.0784)\end{array}$ & $\begin{array}{c}0.5763 \\
(0.0788)\end{array}$ & $\begin{array}{c}0.5593 \\
(0.0787)\end{array}$ \\
\hline \multicolumn{7}{|l|}{ Housing Variables } \\
\hline Log Home Value & $\begin{array}{c}0.0318 \\
(0.0103)\end{array}$ & $\begin{array}{c}0.0320 \\
(0.0104)\end{array}$ & & & & \\
\hline Home Equity & & & $\begin{array}{c}-0.3296 \\
(0.1724)\end{array}$ & $\begin{array}{c}-0.2745 \\
(0.1676)\end{array}$ & & \\
\hline Home Equity Spline Part 1 & & & & & $\begin{array}{c}2.8571 \\
(0.9258)\end{array}$ & $\begin{array}{c}2.7839 \\
(0.9244)\end{array}$ \\
\hline Home Equity Spline Part 2 & & & & & $\begin{array}{c}-0.6861 \\
(0.2278)\end{array}$ & $\begin{array}{c}-0.6030 \\
(0.2250)\end{array}$ \\
\hline Log Mortgage & $\begin{array}{c}-0.0225 \\
(0.00573)\end{array}$ & $\begin{array}{c}-0.0219 \\
(0.00574)\end{array}$ & $\begin{array}{c}-0.0160 \\
(0.00543)\end{array}$ & $\begin{array}{c}-0.0154 \\
(0.00544)\end{array}$ & $\begin{array}{c}-0.0170 \\
(0.00545)\end{array}$ & $\begin{array}{c}-0.0164 \\
(0.00545)\end{array}$ \\
\hline
\end{tabular}


Table 5.

Complementary Log-Log Regression

Housing Variables

(cont'd)

\begin{tabular}{|c|c|c|c|c|c|c|}
\hline Variable & Model 1 & Model 2 & Model 3 & Model 4 & Model 5 & Model 6 \\
\hline \multicolumn{7}{|l|}{ Post - 1999 Variables } \\
\hline Post - 1999 Indicator & $\begin{array}{c}-0.3006 \\
(0.0622)\end{array}$ & & $\begin{array}{c}-0.2838 \\
(0.0625)\end{array}$ & & $\begin{array}{c}-0.2781 \\
(0.0626)\end{array}$ & \\
\hline 2000 Recession $x$ & & -0.1359 & & -0.1308 & & -0.1301 \\
\hline Preretirement Age & & $(0.1446)$ & & $(0.1447)$ & & $(0.1446)$ \\
\hline 2000 Recession x Early & & -0.1349 & & -0.1257 & & -0.1240 \\
\hline Retirement & & $(0.1016)$ & & $(0.1016)$ & & $(0.1017)$ \\
\hline 2000 Recession x Normal & & 0.0230 & & 0.0168 & & 0.0151 \\
\hline Retirement & & $(0.1271)$ & & $(0.1273)$ & & $(0.1273)$ \\
\hline Expansion x Preretirement & & -0.2620 & & -0.2475 & & -0.2412 \\
\hline Age & & $(0.1538)$ & & $(0.1540)$ & & $(0.1541)$ \\
\hline Expansion x Early & & -0.4315 & & -0.4099 & & -0.3986 \\
\hline Retirement & & $(0.0952)$ & & $(0.0956)$ & & $(0.0958)$ \\
\hline Expansion x Normal & & 0.1084 & & 0.1247 & & 0.1239 \\
\hline Retirement & & $(0.1574)$ & & $(0.1572)$ & & $(0.1571)$ \\
\hline 2008 Recession $\mathrm{x}$ & & -0.5217 & & -0.4924 & & -0.5048 \\
\hline Preretirement Age & & $(0.4134)$ & & $(0.4127)$ & & $(0.4133)$ \\
\hline 2008 Recession x Early & & -1.5824 & & -1.5579 & & -1.5526 \\
\hline Retirement & & $(0.3378)$ & & $(0.3380)$ & & $(0.3382)$ \\
\hline 2008 Recession x Normal & & -1.4223 & & -1.4128 & & -1.4003 \\
\hline Retirement & & $(0.4848)$ & & $(0.4849)$ & & $(0.4847)$ \\
\hline
\end{tabular}


Table 5.

Complementary Log-Log Regression

Housing Variables

(cont'd)

\begin{tabular}{lcccccc}
\hline Variable & Model 1 & Model 2 & Model 3 & Model 4 & Model 5 & Model 6 \\
\hline \multirow{2}{*}{ Age Indicators } & & & & & & \\
Age 59 & -2.8875 & -2.9187 & -2.5476 & -2.5799 & -2.7266 & -2.7541 \\
& $(0.1713)$ & $(0.1743)$ & $(0.1399)$ & $(0.1427)$ & $(0.1498)$ & $(0.1525)$ \\
Age 60 & -2.5437 & -2.5802 & -2.2004 & -2.2381 & -2.3808 & -2.4133 \\
& $(0.1653)$ & $(0.1696)$ & $(0.1322)$ & $(0.1366)$ & $(0.1426)$ & $(0.1468)$ \\
Age 61 & -2.3687 & -2.4073 & -2.0264 & -2.0659 & -2.2063 & -2.2402 \\
& $(0.1642)$ & $(0.1696)$ & $(0.1307)$ & $(0.1365)$ & $(0.1413)$ & $(0.1467)$ \\
Age 62 & -1.2095 & -1.1887 & -0.8704 & -0.8529 & -1.0504 & -1.0284 \\
& $(0.1478)$ & $(0.1503)$ & $(0.1104)$ & $(0.1129)$ & $(0.1226)$ & $(0.1251)$ \\
Age 63 & -1.4891 & -1.4646 & -1.1497 & -1.1278 & -1.3289 & -1.3048 \\
& $(0.1571)$ & $(0.1598)$ & $(0.1228)$ & $(0.1254)$ & $(0.1339)$ & $(0.1367)$ \\
Age 64 & -1.6882 & -1.6538 & -1.3393 & -1.3088 & -1.5240 & -1.4906 \\
& $(0.1692)$ & $(0.1723)$ & $(0.1371)$ & $(0.1400)$ & $(0.1476)$ & $(0.1507)$ \\
Age 65 & -1.2335 & -1.3323 & -0.8822 & -0.9827 & -1.0667 & -1.1610 \\
& $(0.1655)$ & $(0.1711)$ & $(0.1324)$ & $(0.1390)$ & $(0.1433)$ & $(0.1497)$ \\
Age 66 & -1.2030 & -1.4923 & -0.8525 & -1.1461 & -1.0269 & -1.3110 \\
& $(0.1761)$ & $(0.2214)$ & $(0.1459)$ & $(0.1985)$ & $(0.1550)$ & $(0.2052)$ \\
Age 67 & -1.7778 & -2.0245 & -1.4289 & -1.6743 & -1.5973 & -1.8332 \\
& $(0.2173)$ & $(0.2669)$ & $(0.1943)$ & $(0.2486)$ & $(0.2009)$ & $(0.2536)$ \\
Age 68 & -1.9313 & -2.2241 & -1.5805 & -1.8732 & -1.7521 & -2.0377 \\
& $(0.2546)$ & $(0.3091)$ & $(0.2351)$ & $(0.2937)$ & $(0.2406)$ & $(0.2981)$ \\
Age 69 & -1.8928 & -2.2184 & -1.5389 & -1.8603 & -1.7140 & -2.0271 \\
& $(0.2819)$ & $(0.3359)$ & $(0.2642)$ & $(0.3213)$ & $(0.2691)$ & $(0.3254)$ \\
Age 70 & -2.1547 & -2.3925 & -1.7922 & -2.0317 & -1.9675 & -2.1949 \\
Age 71-76 & $(0.3487)$ & $(0.3993)$ & $(0.3342)$ & $(0.3872)$ & $(0.3383)$ & $(0.3905)$ \\
& -2.2045 & -2.6043 & -1.8143 & -2.2089 & -1.9996 & -2.3823 \\
Log-Likelihood & $(0.2801)$ & $(0.3251)$ & $(0.2609)$ & $(0.3089)$ & $(0.2664)$ & $(0.3137)$ \\
\hline & -3639.10 & -3611.86 & -3641.75 & -3615.13 & 3635.21 & -3609.11 \\
\hline
\end{tabular}


Table 6.

Complementary Log-Log Regression

Financial Variables

\begin{tabular}{|c|c|c|c|c|}
\hline Variable & Model 1 & Model 2 & Model 3 & Model 4 \\
\hline \multicolumn{5}{|l|}{ Demographic Variables } \\
\hline Black & $\begin{array}{l}-0.0618 \\
(0.0993)\end{array}$ & $\begin{array}{l}-0.0661 \\
(0.0993)\end{array}$ & $\begin{array}{l}-0.0933 \\
(0.0976)\end{array}$ & $\begin{array}{l}-0.0950 \\
(0.0976)\end{array}$ \\
\hline Other Race & $\begin{array}{c}0.0168 \\
(0.1772)\end{array}$ & $\begin{array}{c}0.0287 \\
(0.1772)\end{array}$ & $\begin{array}{l}-0.0717 \\
(0.1755)\end{array}$ & $\begin{array}{l}-0.0610 \\
(0.1756)\end{array}$ \\
\hline College & $\begin{array}{l}-0.3448 \\
(0.0724)\end{array}$ & $\begin{array}{l}-0.3360 \\
(0.0725)\end{array}$ & $\begin{array}{l}-0.2968 \\
(0.0721)\end{array}$ & $\begin{array}{l}-0.2916 \\
(0.0722)\end{array}$ \\
\hline Health Very Good & $\begin{array}{l}-0.1431 \\
(0.0585)\end{array}$ & $\begin{array}{l}-0.1566 \\
(0.0586)\end{array}$ & $\begin{array}{l}-0.1277 \\
(0.0582)\end{array}$ & $\begin{array}{l}-0.1416 \\
(0.0583)\end{array}$ \\
\hline Spouse Disabled & $\begin{array}{c}0.0879 \\
(0.1057)\end{array}$ & $\begin{array}{c}0.0990 \\
(0.1060)\end{array}$ & $\begin{array}{c}0.0767 \\
(0.1053)\end{array}$ & $\begin{array}{c}0.0901 \\
(0.1055)\end{array}$ \\
\hline Spouse Retired & $\begin{array}{c}0.1162 \\
(0.0917)\end{array}$ & $\begin{array}{c}0.1131 \\
(0.0918)\end{array}$ & $\begin{array}{c}0.1304 \\
(0.0913)\end{array}$ & $\begin{array}{c}0.1257 \\
(0.0914)\end{array}$ \\
\hline Spouse Homemaker & $\begin{array}{l}-0.2056 \\
(0.0822)\end{array}$ & $\begin{array}{l}-0.2064 \\
(0.0826)\end{array}$ & $\begin{array}{l}-0.2012 \\
(0.0819)\end{array}$ & $\begin{array}{l}-0.2034 \\
(0.0824)\end{array}$ \\
\hline $\begin{array}{l}\text { Spouse Homemaker x Years } \\
\text { Off }\end{array}$ & $\begin{array}{l}-0.0747 \\
(0.0380)\end{array}$ & $\begin{array}{l}-0.0651 \\
(0.0411)\end{array}$ & $\begin{array}{l}-0.0749 \\
(0.0379)\end{array}$ & $\begin{array}{l}-0.0652 \\
(0.0410)\end{array}$ \\
\hline \multicolumn{5}{|l|}{ Workplace Variables } \\
\hline Log Spouse Income & $\begin{array}{l}-0.0269 \\
(0.00742)\end{array}$ & $\begin{array}{c}-0.0269 \\
(0.00744)\end{array}$ & $\begin{array}{c}-0.0296 \\
(0.00741)\end{array}$ & $\begin{array}{c}-0.0298 \\
(0.00743)\end{array}$ \\
\hline Log Own Income & $\begin{array}{c}-0.0666 \\
(0.00725)\end{array}$ & $\begin{array}{c}-0.0649 \\
(0.00725)\end{array}$ & $\begin{array}{c}-0.0691 \\
(0.00728)\end{array}$ & $\begin{array}{c}-0.0674 \\
(0.00728)\end{array}$ \\
\hline Defined Benefit Plan & $\begin{array}{l}1.1213 \\
(0.0824)\end{array}$ & $\begin{array}{l}1.1126 \\
(0.0822)\end{array}$ & $\begin{array}{c}1.1245 \\
(0.0825)\end{array}$ & $\begin{array}{c}1.1157 \\
(0.0823)\end{array}$ \\
\hline Defined Contribution Plan & $\begin{array}{c}0.5759 \\
(0.0788)\end{array}$ & $\begin{array}{c}0.5589 \\
(0.0787)\end{array}$ & $\begin{array}{c}0.5885 \\
(0.0789)\end{array}$ & $\begin{array}{c}0.5712 \\
(0.0787)\end{array}$ \\
\hline \\
\hline Log Home Value & $\begin{array}{c}0.0349 \\
(0.0111)\end{array}$ & $\begin{array}{c}0.0354 \\
(0.0112)\end{array}$ & & \\
\hline Home Equity & & & $\begin{array}{l}-0.1712 \\
(0.1795)\end{array}$ & $\begin{array}{l}-0.1111 \\
(0.1668)\end{array}$ \\
\hline Log Mortgage & $\begin{array}{c}-0.0234 \\
(0.0058)\end{array}$ & $\begin{array}{l}-0.0228 \\
(0.00583)\end{array}$ & $\begin{array}{c}-0.0172 \\
(0.00545)\end{array}$ & $\begin{array}{c}-0.0167 \\
(0.00545)\end{array}$ \\
\hline \multicolumn{5}{|l|}{ Financial Variables } \\
\hline Zero Financial Assets & $\begin{array}{l}-0.3978 \\
(0.2548)\end{array}$ & $\begin{array}{c}-0.3533 \\
(0.2554)\end{array}$ & $\begin{array}{c}-0.2670 \\
(0.1602)\end{array}$ & $\begin{array}{l}-0.2262 \\
(0.1599)\end{array}$ \\
\hline Log Financial Assets & $\begin{array}{c}-0.0246 \\
(0.0187)\end{array}$ & $\begin{array}{c}-0.0239 \\
(0.0188)\end{array}$ & & \\
\hline Financial Assets (> 0) & & & $\begin{array}{l}-0.1117 \\
(0.0688)\end{array}$ & $\begin{array}{l}-0.1149 \\
(0.0681)\end{array}$ \\
\hline Squared Financial Assets (>0) & & & $\begin{array}{c}-0.00201 \\
(0.0645)\end{array}$ & $\begin{array}{c}-0.00143 \\
(0.0637)\end{array}$ \\
\hline
\end{tabular}


Table 6.

Complementary Log-Log Regression

Financial Variables

(cont'd)

\begin{tabular}{|c|c|c|c|c|}
\hline Variable & Model 1 & Model 2 & Model 3 & Model 4 \\
\hline \multicolumn{5}{|l|}{ Post - 1999 Variables } \\
\hline Post - 1999 Indicator & $\begin{array}{l}-0.2977 \\
(0.0622)\end{array}$ & & $\begin{array}{l}-0.2837 \\
(0.0626)\end{array}$ & \\
\hline $\begin{array}{l}2000 \text { Recession x } \\
\text { Preretirement Age }\end{array}$ & & $\begin{array}{l}-0.1347 \\
(0.1446)\end{array}$ & & $\begin{array}{l}-0.1305 \\
(0.1447)\end{array}$ \\
\hline 2000 Recession x Early & & -0.1353 & & -0.1295 \\
\hline Retirement & & $(0.1016)$ & & $(0.1016)$ \\
\hline 2000 Recession x Normal & & 0.0230 & & 0.0248 \\
\hline Retirement & & $(0.1271)$ & & $(0.1273)$ \\
\hline Expansion x Preretirement Age & & $\begin{array}{l}-0.2589 \\
(0.1538)\end{array}$ & & $\begin{array}{l}-0.2441 \\
(0.1540)\end{array}$ \\
\hline Expansion x Early Retirement & & $\begin{array}{l}-0.4266 \\
(0.0952)\end{array}$ & & $\begin{array}{l}-0.4076 \\
(0.0957)\end{array}$ \\
\hline Expansion x Normal & & 0.1084 & & 0.1132 \\
\hline Retirement & & $(0.1573)$ & & $(0.1572)$ \\
\hline 2008 Recession $\mathrm{x}$ & & -0.5119 & & -0.5073 \\
\hline Preretirement Age & & $(0.4131)$ & & $(0.4128)$ \\
\hline 2008 Recession x Early & & -1.5770 & & -1.5558 \\
\hline Retirement & & $(0.3378)$ & & $(0.3381)$ \\
\hline 2008 Recession x Normal & & -1.4248 & & -1.4222 \\
\hline Retirement & & $(0.4848)$ & & $(0.4848)$ \\
\hline
\end{tabular}


Table 6.

Complementary Log-Log Regression

Financial Variables

(cont'd)

\begin{tabular}{lcccc}
\hline Variable & Model 1 & Model 2 & Model 3 & Model 4 \\
\hline Age Indicators & & & & \\
Age 59 & -2.6241 & -2.6700 & -2.4899 & -2.5249 \\
Age 60 & $(0.2507)$ & $(0.2529)$ & $(0.1416)$ & $(0.1443)$ \\
& -2.2807 & -2.3316 & -2.1431 & -2.1833 \\
Age 61 & $(0.2466)$ & $(0.2497)$ & $(0.1339)$ & $(0.1382)$ \\
& -2.1030 & -2.1566 & -1.9659 & -2.0084 \\
Age 62 & $(0.2468)$ & $(0.2506)$ & $(0.1325)$ & $(0.1382)$ \\
& -0.9423 & -0.9364 & -0.8087 & -0.7940 \\
Age 63 & $(0.2366)$ & $(0.2384)$ & $(0.1127)$ & $(0.1151)$ \\
& -1.2216 & -1.2121 & -1.0903 & -1.0710 \\
Age 64 & $(0.2434)$ & $(0.2455)$ & $(0.1249)$ & $(0.1275)$ \\
Age 65 & -1.4231 & -1.4040 & -1.2817 & -1.2534 \\
& $(0.2506)$ & $(0.2525)$ & $(0.1388)$ & $(0.1417)$ \\
Age 66 & -0.9677 & -1.0807 & -0.8239 & -0.9268 \\
& $(0.2482)$ & $(0.2523)$ & $(0.1342)$ & $(0.1405)$ \\
Age 67 & -0.9351 & -1.2373 & -0.7835 & -1.0743 \\
& $(0.2562)$ & $(0.2900)$ & $(0.1480)$ & $(0.1998)$ \\
Age 68 & -1.5034 & -1.7637 & -1.3521 & -1.5945 \\
& $(0.2877)$ & $(0.3278)$ & $(0.1959)$ & $(0.2495)$ \\
Age 69 & -1.6589 & -1.9648 & -1.5084 & -1.7976 \\
& $(0.3175)$ & $(0.3633)$ & $(0.2367)$ & $(0.2946)$ \\
Age 70 & -1.6205 & -1.9576 & -1.4786 & -1.7955 \\
& $(0.3390)$ & $(0.3865)$ & $(0.2652)$ & $(0.3221)$ \\
Age 71-76 & -1.8839 & -2.1322 & -1.7395 & -1.9760 \\
& $(0.3968)$ & $(0.4434)$ & $(0.3348)$ & $(0.3874)$ \\
\hline \hline \multirow{2}{*}{ Log-Likelihood } & -1.9328 & -2.3446 & -1.7511 & -2.1480 \\
& $(0.3387)$ & $(0.3781)$ & $(0.2624)$ & $(0.3097)$ \\
\hline
\end{tabular}


Table 7.

Complementary Log-Log Regression

Financial Splines

\begin{tabular}{|c|c|c|c|c|}
\hline Variable & Model 1 & Model 2 & Model 3 & Model 4 \\
\hline \multicolumn{5}{|l|}{ Demographic Variables } \\
\hline Black & $\begin{array}{l}-0.0660 \\
(0.0975)\end{array}$ & $\begin{array}{l}-0.0703 \\
(0.0975)\end{array}$ & $\begin{array}{l}-0.0104 \\
(0.0993)\end{array}$ & $\begin{array}{l}-0.0147 \\
(0.0993)\end{array}$ \\
\hline Other Race & $\begin{array}{c}0.0179 \\
(0.1768)\end{array}$ & $\begin{array}{c}0.0294 \\
(0.1769)\end{array}$ & $\begin{array}{c}0.0449 \\
(0.1769)\end{array}$ & $\begin{array}{c}0.0548 \\
(0.1769)\end{array}$ \\
\hline College & $\begin{array}{l}-0.3071 \\
(0.0713)\end{array}$ & $\begin{array}{l}-0.2997 \\
(0.0714)\end{array}$ & $\begin{array}{l}-0.3350 \\
(0.0719)\end{array}$ & $\begin{array}{l}-0.3270 \\
(0.0720)\end{array}$ \\
\hline Health Very Good & $\begin{array}{l}-0.1363 \\
(0.0581)\end{array}$ & $\begin{array}{l}-0.1499 \\
(0.0582)\end{array}$ & $\begin{array}{l}-0.1566 \\
(0.0584)\end{array}$ & $\begin{array}{l}-0.1702 \\
(0.0585)\end{array}$ \\
\hline Spouse Disabled & $\begin{array}{c}0.0844 \\
(0.1054)\end{array}$ & $\begin{array}{c}0.0974 \\
(0.1057)\end{array}$ & $\begin{array}{c}0.1086 \\
(0.1055)\end{array}$ & $\begin{array}{c}0.1223 \\
(0.1058)\end{array}$ \\
\hline Spouse Retired & $\begin{array}{c}0.1177 \\
(0.0915)\end{array}$ & $\begin{array}{c}0.1132 \\
(0.0917)\end{array}$ & $\begin{array}{c}0.1007 \\
(0.0917)\end{array}$ & $\begin{array}{c}0.0954 \\
(0.0919)\end{array}$ \\
\hline Spouse Homemaker & $\begin{array}{l}-0.2079 \\
(0.0821)\end{array}$ & $\begin{array}{l}-0.2117 \\
(0.0826)\end{array}$ & $\begin{array}{l}-0.2022 \\
(0.0821)\end{array}$ & $\begin{array}{l}-0.2069 \\
(0.0826)\end{array}$ \\
\hline $\begin{array}{l}\text { Spouse Homemaker x Years } \\
\text { Off }\end{array}$ & $\begin{array}{l}-0.0744 \\
(0.0379)\end{array}$ & $\begin{array}{l}-0.0636 \\
(0.0410)\end{array}$ & $\begin{array}{l}-0.0675 \\
(0.0378)\end{array}$ & $\begin{array}{l}-0.0560 \\
(0.0410)\end{array}$ \\
\hline \multicolumn{5}{|l|}{ Workplace Variables } \\
\hline Log Spouse Income & $\begin{array}{c}-0.0286 \\
(0.00743)\end{array}$ & $\begin{array}{c}-0.0289 \\
(0.00745)\end{array}$ & $\begin{array}{l}-0.0300 \\
(0.00743)\end{array}$ & $\begin{array}{c}-0.0304 \\
(0.00745)\end{array}$ \\
\hline Log Own Income & $\begin{array}{c}-0.0693 \\
(0.00726)\end{array}$ & $\begin{array}{l}-0.0675 \\
(0.00727)\end{array}$ & $\begin{array}{c}-0.0676 \\
(0.00729)\end{array}$ & $\begin{array}{l}-0.0658 \\
(0.00729)\end{array}$ \\
\hline Defined Benefit Plan & $\begin{array}{c}1.1171 \\
(0.0826)\end{array}$ & $\begin{array}{l}1.1082 \\
(0.0824)\end{array}$ & $\begin{array}{c}1.1151 \\
(0.0829)\end{array}$ & $\begin{array}{c}1.1057 \\
(0.0827)\end{array}$ \\
\hline Defined Contribution Plan & $\begin{array}{c}0.5782 \\
(0.0790)\end{array}$ & $\begin{array}{c}0.5616 \\
(0.0788)\end{array}$ & $\begin{array}{c}0.5718 \\
(0.0792)\end{array}$ & $\begin{array}{c}0.5553 \\
(0.0791)\end{array}$ \\
\hline \multicolumn{5}{|l|}{ Housing Variables } \\
\hline Log Home Value & $\begin{array}{c}0.0395 \\
(0.0106)\end{array}$ & $\begin{array}{c}0.0396 \\
(0.0107)\end{array}$ & $\begin{array}{c}0.0302 \\
(0.0110)\end{array}$ & $\begin{array}{c}0.0304 \\
(0.0110)\end{array}$ \\
\hline Log Mortgage & $\begin{array}{l}-0.0257 \\
(0.00577)\end{array}$ & $\begin{array}{c}-0.0251 \\
(0.00578)\end{array}$ & $\begin{array}{l}-0.0236 \\
(0.00581)\end{array}$ & $\begin{array}{c}-0.0230 \\
(0.00582)\end{array}$ \\
\hline \multicolumn{5}{|l|}{ Financial Variables } \\
\hline Financial Assets & $\begin{array}{l}-0.1540 \\
(0.0455)\end{array}$ & $\begin{array}{l}-0.1519 \\
(0.0453)\end{array}$ & & \\
\hline Financial Assets Spline Part 1 & & & $\begin{array}{c}2.2932 \\
(0.7960)\end{array}$ & $\begin{array}{c}2.2823 \\
(0.7969)\end{array}$ \\
\hline Financial Assets Spline Part 2 & & & $\begin{array}{c}-0.1948 \\
(0.0514)\end{array}$ & $\begin{array}{c}-0.1923 \\
(0.0511)\end{array}$ \\
\hline
\end{tabular}


Table 7.

Complementary Log-Log Regression

Financial Splines

(cont'd)

\begin{tabular}{|c|c|c|c|c|}
\hline Variable & Model 1 & Model 2 & Model 3 & Model 4 \\
\hline \multicolumn{5}{|l|}{ Post - 1999 Variables } \\
\hline Post - 1999 Indicator & $\begin{array}{c}-0.2985 \\
(0.0622)\end{array}$ & & $\begin{array}{c}-0.2969 \\
(0.0622)\end{array}$ & \\
\hline 2000 Recession $x$ & & -0.1327 & & -0.1333 \\
\hline Preretirement Age & & $(0.1446)$ & & $(0.1446)$ \\
\hline 2000 Recession x Early & & -0.1339 & & -0.1343 \\
\hline Retirement & & $(0.1016)$ & & $(0.1017)$ \\
\hline 2000 Recession $x$ & & 0.0222 & & 0.0360 \\
\hline Normal Retirement & & $(0.1271)$ & & $(0.1272)$ \\
\hline Expansion $\mathrm{x}$ & & -0.2530 & & -0.2452 \\
\hline Preretirement Age & & $(0.1537)$ & & $(0.1537)$ \\
\hline Expansion x Early & & -0.4226 & & -0.4238 \\
\hline Retirement & & $(0.0952)$ & & $(0.0952)$ \\
\hline Expansion x Normal & & 0.0952 & & 0.0880 \\
\hline Retirement & & $(0.1571)$ & & $(0.1572)$ \\
\hline 2008 Recession $\mathrm{x}$ & & -0.5302 & & -0.5422 \\
\hline Preretirement Age & & $(0.4133)$ & & $(0.4142)$ \\
\hline 2008 Recession x Early & & -1.5829 & & -1.5779 \\
\hline Retirement & & $(0.3378)$ & & $(0.3379)$ \\
\hline 2008 Recession $x$ & & -1.4468 & & -1.4397 \\
\hline Normal Retirement & & $(0.4848)$ & & $(0.4848)$ \\
\hline
\end{tabular}


Table 7.

Complementary Log-Log Regression

Financial Splines

(cont'd)

\begin{tabular}{lcccc}
\hline Variable & Model 1 & Model 2 & Model 3 & Model 4 \\
\hline Age Indicators & & & & \\
Age 59 & -2.8776 & -2.9102 & -2.9475 & -2.9804 \\
& $(0.1724)$ & $(0.1753)$ & $(0.1736)$ & $(0.1766)$ \\
Age 60 & -2.5333 & -2.5715 & -2.6025 & -2.6410 \\
& $(0.1665)$ & $(0.1707)$ & $(0.1677)$ & $(0.1719)$ \\
Age 61 & -2.3576 & -2.3981 & -2.4302 & -2.4709 \\
& $(0.1653)$ & $(0.1706)$ & $(0.1666)$ & $(0.1719)$ \\
Age 62 & -1.1965 & -1.1778 & -1.2685 & -1.2493 \\
& $(0.1491)$ & $(0.1516)$ & $(0.1505)$ & $(0.1530)$ \\
Age 63 & -1.4773 & -1.4546 & -1.5500 & -1.5268 \\
& $(0.1583)$ & $(0.1611)$ & $(0.1597)$ & $(0.1624)$ \\
Age 64 & -1.6745 & -1.6422 & -1.7420 & -1.7065 \\
& $(0.1702)$ & $(0.1733)$ & $(0.1713)$ & $(0.1743)$ \\
Age 65 & -1.2142 & -1.3117 & -1.2832 & -1.3803 \\
& $(0.1666)$ & $(0.1722)$ & $(0.1678)$ & $(0.1732)$ \\
Age 66 & -1.1728 & -1.4522 & -1.2384 & -1.5162 \\
& $(0.1772)$ & $(0.2220)$ & $(0.1782)$ & $(0.2228)$ \\
Age 67 & -1.7421 & -1.9701 & -1.8140 & -2.0424 \\
& $(0.2180)$ & $(0.2669)$ & $(0.2191)$ & $(0.2679)$ \\
Age 68 & -1.8963 & -2.1717 & -1.9706 & -2.2461 \\
& $(0.2556)$ & $(0.3097)$ & $(0.2567)$ & $(0.3107)$ \\
Age 69 & -1.8748 & -2.1812 & -1.9473 & -2.2572 \\
& $(0.2826)$ & $(0.3365)$ & $(0.2834)$ & $(0.3372)$ \\
Age 70 & -2.1300 & -2.3493 & -2.2123 & -2.4383 \\
Age 71-76 & $(0.3491)$ & $(0.3994)$ & $(0.3500)$ & $(0.4003)$ \\
& -2.1660 & -2.5536 & -2.2420 & -2.6369 \\
Log-Likelihood & $(0.2808)$ & $(0.3252)$ & $(0.2818)$ & $(0.3262)$ \\
\hline
\end{tabular}


Table 8.

Complementary Log-Log Regression Home Equity

\begin{tabular}{|c|c|c|c|c|}
\hline Variable & Model 1 & Model 2 & Model 3 & Model 4 \\
\hline \multicolumn{5}{|l|}{ Demographic Variables } \\
\hline Black & $\begin{array}{l}-0.1047 \\
(0.0971)\end{array}$ & $\begin{array}{c}-0.1051 \\
(0.0971)\end{array}$ & $\begin{array}{c}-0.0249 \\
(0.0991)\end{array}$ & $\begin{array}{l}-0.0266 \\
(0.0991)\end{array}$ \\
\hline Other Race & $\begin{array}{l}-0.0822 \\
(0.1754)\end{array}$ & $\begin{array}{c}-0.0690 \\
(0.1755)\end{array}$ & $\begin{array}{c}-0.0211 \\
(0.1758)\end{array}$ & $\begin{array}{l}-0.0107 \\
(0.1759)\end{array}$ \\
\hline College & $\begin{array}{l}-0.2955 \\
(0.0715)\end{array}$ & $\begin{array}{l}-0.2910 \\
(0.0716)\end{array}$ & $\begin{array}{l}-0.3315 \\
(0.0720)\end{array}$ & $\begin{array}{c}-0.3264 \\
(0.0721)\end{array}$ \\
\hline Health Very Good & $\begin{array}{c}-0.1216 \\
(0.0581)\end{array}$ & $\begin{array}{c}-0.1366 \\
(0.0582)\end{array}$ & $\begin{array}{c}-0.1502 \\
(0.0585)\end{array}$ & $\begin{array}{l}-0.1647 \\
(0.0586)\end{array}$ \\
\hline Spouse Disabled & $\begin{array}{c}0.0739 \\
(0.1052)\end{array}$ & $\begin{array}{c}0.0880 \\
(0.1055)\end{array}$ & $\begin{array}{c}0.1077 \\
(0.1054)\end{array}$ & $\begin{array}{c}0.1221 \\
(0.1056)\end{array}$ \\
\hline Spouse Retired & $\begin{array}{c}0.1381 \\
(0.0911)\end{array}$ & $\begin{array}{c}0.1313 \\
(0.0913)\end{array}$ & $\begin{array}{c}0.1082 \\
(0.0915)\end{array}$ & $\begin{array}{c}0.1014 \\
(0.0917)\end{array}$ \\
\hline Spouse Homemaker & $\begin{array}{l}-0.1970 \\
(0.0818)\end{array}$ & $\begin{array}{l}-0.2008 \\
(0.0823)\end{array}$ & $\begin{array}{l}-0.1927 \\
(0.0819)\end{array}$ & $\begin{array}{c}-0.1971 \\
(0.0824)\end{array}$ \\
\hline Spouse Homemaker x Years Off & $\begin{array}{l}-0.0783 \\
(0.0379)\end{array}$ & $\begin{array}{l}-0.0682 \\
(0.0410)\end{array}$ & $\begin{array}{c}-0.0679 \\
(0.0378)\end{array}$ & $\begin{array}{c}-0.0569 \\
(0.0410)\end{array}$ \\
\hline \multicolumn{5}{|l|}{ Workplace Variables } \\
\hline Log Spouse Income & $\begin{array}{c}-0.0289 \\
(0.00740)\end{array}$ & $\begin{array}{c}-0.0292 \\
(0.00742)\end{array}$ & $\begin{array}{c}-0.0308 \\
(0.00741)\end{array}$ & $\begin{array}{c}-0.0312 \\
(0.00743)\end{array}$ \\
\hline Log Own Income & $\begin{array}{c}-0.0692 \\
(0.00725)\end{array}$ & $\begin{array}{c}-0.0675 \\
(0.00726)\end{array}$ & $\begin{array}{c}-0.0671 \\
(0.00728)\end{array}$ & $\begin{array}{c}-0.0654 \\
(0.00729)\end{array}$ \\
\hline Defined Benefit Plan & $\begin{array}{c}1.1287 \\
(0.0823)\end{array}$ & $\begin{array}{c}1.1200 \\
(0.0821)\end{array}$ & $\begin{array}{c}1.1228 \\
(0.0827)\end{array}$ & $\begin{array}{c}1.1132 \\
(0.0825)\end{array}$ \\
\hline Defined Contribution Plan & $\begin{array}{c}0.5935 \\
(0.0787)\end{array}$ & $\begin{array}{c}0.5759 \\
(0.0786)\end{array}$ & $\begin{array}{c}0.5818 \\
(0.0791)\end{array}$ & $\begin{array}{c}0.5643 \\
(0.0790)\end{array}$ \\
\hline \multicolumn{5}{|l|}{ Housing Variables } \\
\hline Home Equity & $\begin{array}{c}-0.1531 \\
(0.1723)\end{array}$ & $\begin{array}{c}-0.0981 \\
(0.1600)\end{array}$ & $\begin{array}{c}-0.2824 \\
(0.1964)\end{array}$ & $\begin{array}{c}-0.2091 \\
(0.1905)\end{array}$ \\
\hline Log Mortgage & $\begin{array}{c}-0.0172 \\
(0.00544)\end{array}$ & $\begin{array}{c}-0.0167 \\
(0.00545)\end{array}$ & $\begin{array}{c}-0.0170 \\
(0.00544)\end{array}$ & $\begin{array}{c}-0.0165 \\
(0.00545)\end{array}$ \\
\hline \multicolumn{5}{|l|}{ Financial Variables } \\
\hline Financial Assets & $\begin{array}{l}-0.1091 \\
(0.0437)\end{array}$ & $\begin{array}{l}-0.1123 \\
(0.0438)\end{array}$ & & \\
\hline Financial Assets Spline Part 1 & & & $\begin{array}{c}3.1626 \\
(0.7754)\end{array}$ & $\begin{array}{c}3.0899 \\
(0.7758)\end{array}$ \\
\hline Financial Assets Spline Part 2 & & & $\begin{array}{c}-0.1563 \\
(0.0512)\end{array}$ & $\begin{array}{c}-0.1597 \\
(0.0513)\end{array}$ \\
\hline
\end{tabular}


Table 8.

Complementary Log-Log Regression

Home Equity

(cont'd)

\begin{tabular}{|c|c|c|c|c|}
\hline Variable & Model 1 & Model 2 & Model 3 & Model 4 \\
\hline \multicolumn{5}{|l|}{ Post - 1999 Variables } \\
\hline Post - 1999 Indicator & $\begin{array}{l}-0.2879 \\
(0.0625)\end{array}$ & & $\begin{array}{l}-0.2820 \\
(0.0626)\end{array}$ & \\
\hline $\begin{array}{l}2000 \text { Recession x Preretirement } \\
\text { Age }\end{array}$ & & $\begin{array}{r}-0.1315 \\
(0.1447)\end{array}$ & & $\begin{array}{r}-0.1305 \\
(0.1446)\end{array}$ \\
\hline 2000 Recession x Early & & -0.1290 & & -0.1286 \\
\hline Retirement & & $(0.1016)$ & & $(0.1017)$ \\
\hline 2000 Recession x Normal & & 0.0219 & & 0.0343 \\
\hline Retirement & & $(0.1273)$ & & $(0.1274)$ \\
\hline Expansion x Preretirement Age & & $\begin{array}{l}-0.2499 \\
(0.1540)\end{array}$ & & $\begin{array}{c}-0.2329 \\
(0.1541)\end{array}$ \\
\hline Expansion x Early Retirement & & $\begin{array}{l}-0.4129 \\
(0.0956)\end{array}$ & & $\begin{array}{c}-0.4086 \\
(0.0958)\end{array}$ \\
\hline Expansion x Normal Retirement & & $\begin{array}{c}0.1134 \\
(0.1570)\end{array}$ & & $\begin{array}{c}0.1051 \\
(0.1572)\end{array}$ \\
\hline 2008 Recession x Preretirement & & -0.5090 & & -0.5240 \\
\hline Age & & $(0.4127)$ & & $(0.4141)$ \\
\hline 2008 Recession x Early & & -1.5674 & & -1.5558 \\
\hline Retirement & & $(0.3380)$ & & $(0.3381)$ \\
\hline 2008 Recession x Normal & & -1.4287 & & -1.4193 \\
\hline Retirement & & $(0.4849)$ & & $(0.4849)$ \\
\hline
\end{tabular}


Table 8.

Complementary Log-Log Regression

Home Equity

(cont'd)

\begin{tabular}{lcccc}
\hline Variable & Model 1 & Model 2 & Model 3 & Model 4 \\
\hline \multirow{2}{*}{ Age Indicators } & & & & \\
Age 59 & -2.5099 & -2.5406 & -2.7081 & -2.7365 \\
& $(0.1405)$ & $(0.1432)$ & $(0.1489)$ & $(0.1516)$ \\
Age 60 & -2.1622 & -2.1984 & -2.3600 & -2.3939 \\
& $(0.1329)$ & $(0.1372)$ & $(0.1416)$ & $(0.1457)$ \\
Age 61 & -1.9874 & -2.0255 & -2.1897 & -2.2256 \\
& $(0.1313)$ & $(0.1370)$ & $(0.1405)$ & $(0.1460)$ \\
Age 62 & -0.8309 & -0.8117 & -1.0317 & -1.0090 \\
& $(0.1112)$ & $(0.1137)$ & $(0.1217)$ & $(0.1240)$ \\
Age 63 & -1.1120 & -1.0878 & -1.3123 & -1.2854 \\
& $(0.1235)$ & $(0.1261)$ & $(0.1330)$ & $(0.1356)$ \\
Age 64 & -1.3012 & -1.2687 & -1.4959 & -1.4571 \\
& $(0.1376)$ & $(0.1406)$ & $(0.1458)$ & $(0.1485)$ \\
Age 65 & -0.8418 & -0.9411 & -1.0368 & -1.1313 \\
& $(0.1331)$ & $(0.1395)$ & $(0.1415)$ & $(0.1476)$ \\
Age 66 & -0.8048 & -1.0929 & -0.9950 & -1.2748 \\
& $(0.1466)$ & $(0.1987)$ & $(0.1541)$ & $(0.2042)$ \\
Age 67 & -1.3817 & -1.6173 & -1.5768 & -1.8060 \\
Age 68 & $(0.1948)$ & $(0.2485)$ & $(0.2008)$ & $(0.2532)$ \\
& -1.5326 & -1.8174 & -1.7318 & -2.0089 \\
Age 69 & $(0.2359)$ & $(0.2941)$ & $(0.2411)$ & $(0.2982)$ \\
Age 70 & -1.5034 & -1.8173 & -1.7017 & -2.0118 \\
& $(0.2646)$ & $(0.3216)$ & $(0.2690)$ & $(0.3253)$ \\
Age 71-76 & -1.7575 & -1.9913 & -1.9695 & -2.2001 \\
Age 71-76 & $(0.3344)$ & $(0.3870)$ & $(0.3386)$ & $(0.3907)$ \\
& -1.7678 & -2.1616 & -1.9746 & -2.3662 \\
Log-Likelihood & $(0.2615)$ & $(0.3090)$ & $(0.2663)$ & $(0.3133)$ \\
& -1.9328 & -2.3446 & -1.7511 & -2.1480 \\
& $(0.3387)$ & $(0.3781)$ & $(0.2624)$ & $(0.3097)$ \\
\hline
\end{tabular}


Table 9.

Complementary Log-Log Regression

Home Equity and Financial Splines

\begin{tabular}{|c|c|c|c|c|}
\hline Variable & Model 1 & Model 2 & Model 3 & Model 4 \\
\hline \multicolumn{5}{|l|}{ Demographic Variables } \\
\hline Black & $\begin{array}{c}-0.0531 \\
(0.0984)\end{array}$ & $\begin{array}{c}-0.0562 \\
(0.0983)\end{array}$ & $\begin{array}{c}-0.00422 \\
(0.0996)\end{array}$ & $\begin{array}{c}-0.00741 \\
(0.0995)\end{array}$ \\
\hline Other Race & $\begin{array}{l}-0.0207 \\
(0.1760)\end{array}$ & $\begin{array}{l}-0.00727 \\
(0.1761))\end{array}$ & $\begin{array}{c}0.0101 \\
(0.1762)\end{array}$ & $\begin{array}{c}0.0210 \\
(0.1762)\end{array}$ \\
\hline College & $\begin{array}{c}-0.3008 \\
(0.0717)\end{array}$ & $\begin{array}{l}-0.2974 \\
(0.0718)\end{array}$ & $\begin{array}{c}-0.3279 \\
(0.0721)\end{array}$ & $\begin{array}{l}-0.3237 \\
(0.0721)\end{array}$ \\
\hline Health Very Good & $\begin{array}{c}-0.1371 \\
(0.0583)\end{array}$ & $\begin{array}{c}-0.1519 \\
(0.0584)\end{array}$ & $\begin{array}{c}-0.1553 \\
(0.0585)\end{array}$ & $\begin{array}{c}-0.1699 \\
(0.0586)\end{array}$ \\
\hline Spouse Disabled & $\begin{array}{c}0.0823 \\
(0.1054)\end{array}$ & $\begin{array}{c}0.0956 \\
(0.1057)\end{array}$ & $\begin{array}{c}0.1066 \\
(0.1055)\end{array}$ & $\begin{array}{c}0.1206 \\
(0.1058)\end{array}$ \\
\hline Spouse Retired & $\begin{array}{c}0.1198 \\
(0.0913)\end{array}$ & $\begin{array}{c}0.1150 \\
(0.0915)\end{array}$ & $\begin{array}{c}0.1015 \\
(0.0915)\end{array}$ & $\begin{array}{c}0.0959 \\
(0.0917)\end{array}$ \\
\hline Spouse Homemaker & $\begin{array}{l}-0.1981 \\
(0.0820)\end{array}$ & $\begin{array}{l}-0.2008 \\
(0.0825)\end{array}$ & $\begin{array}{c}-0.1936 \\
(0.0820)\end{array}$ & $\begin{array}{c}-0.1972 \\
(0.0825)\end{array}$ \\
\hline Spouse Homemaker x Years Off & $\begin{array}{c}-0.0731 \\
(0.0378)\end{array}$ & $\begin{array}{l}-0.0622 \\
(0.0410)\end{array}$ & $\begin{array}{c}-0.0662 \\
(0.0377)\end{array}$ & $\begin{array}{c}-0.0548 \\
(0.0410)\end{array}$ \\
\hline \multicolumn{5}{|l|}{ Workplace Variables } \\
\hline Log Spouse Income & $\begin{array}{c}-0.0294 \\
(0.00741)\end{array}$ & $\begin{array}{c}-0.0294 \\
(0.00743)\end{array}$ & $\begin{array}{c}-0.0308 \\
(0.00742)\end{array}$ & $\begin{array}{c}-0.0310 \\
(0.00744)\end{array}$ \\
\hline Log Own Income & $\begin{array}{l}-0.0688 \\
0.00726)\end{array}$ & $\begin{array}{c}-0.0671 \\
(0.00726)\end{array}$ & $\begin{array}{c}-0.0672 \\
(0.00728)\end{array}$ & $\begin{array}{c}-0.0655 \\
(0.00729)\end{array}$ \\
\hline Defined Benefit Plan & $\begin{array}{c}1.1105 \\
(0.0826)\end{array}$ & $\begin{array}{c}1.1030 \\
(0.0824)\end{array}$ & $\begin{array}{c}1.1120 \\
(0.0829)\end{array}$ & $\begin{array}{c}1.1036 \\
(0.0827)\end{array}$ \\
\hline Defined Contribution Plan & $\begin{array}{c}0.5780 \\
(0.0790)\end{array}$ & $\begin{array}{c}0.5615 \\
(0.0788)\end{array}$ & $\begin{array}{c}0.5735 \\
(0.0792)\end{array}$ & $\begin{array}{c}0.5569 \\
(0.0791)\end{array}$ \\
\hline \multicolumn{5}{|l|}{ Housing Variables } \\
\hline Home Equity Spline Part 1 & $\begin{array}{c}3.0125 \\
(0.9302)\end{array}$ & $\begin{array}{c}2.9354 \\
(0.9285)\end{array}$ & $\begin{array}{c}1.9069 \\
(0.9763)\end{array}$ & $\begin{array}{c}1.8593 \\
(0.9732)\end{array}$ \\
\hline Home Equity Spline Part 2 & $\begin{array}{l}-0.4861 \\
(0.2344)\end{array}$ & $\begin{array}{l}-0.3918 \\
(0.2309)\end{array}$ & $\begin{array}{l}-0.5087 \\
(0.2384)\end{array}$ & $\begin{array}{l}-0.4131 \\
(0.2355)\end{array}$ \\
\hline Log Mortgage & $\begin{array}{c}-0.0182 \\
(0.00546)\end{array}$ & $\begin{array}{c}-0.0177 \\
(0.00547)\end{array}$ & $\begin{array}{c}-0.0176 \\
(0.00545)\end{array}$ & $\begin{array}{c}-0.0171 \\
(0.00546)\end{array}$ \\
\hline \multicolumn{5}{|l|}{ Financial Variables } \\
\hline Financial Assets & $\begin{array}{c}-0.1097 \\
(0.0449)\end{array}$ & $\begin{array}{c}-0.1133 \\
(0.0452)\end{array}$ & & \\
\hline Financial Assets Spline Part 1 & & & $\begin{array}{c}2.5817 \\
(0.8158)\end{array}$ & $\begin{array}{c}2.5439 \\
(0.8163)\end{array}$ \\
\hline Financial Assets Spline Part 2 & & & $\begin{array}{c}-0.1480 \\
(0.0510)\end{array}$ & $\begin{array}{l}-0.1516 \\
(0.0513)\end{array}$ \\
\hline
\end{tabular}


Table 9.

Complementary Log-Log Regression

Home Equity and Financial Splines

(cont'd)

\begin{tabular}{|c|c|c|c|c|}
\hline Variable & Model 1 & Model 2 & Model 3 & Model 4 \\
\hline \multicolumn{5}{|l|}{ Post - 1999 Variables } \\
\hline Post - 1999 Indicator & $\begin{array}{c}-0.2823 \\
(0.0626)\end{array}$ & & $\begin{array}{c}-0.2784 \\
(0.0627)\end{array}$ & \\
\hline 2000 Recession x Preretirement & & -0.1305 & & -0.1300 \\
\hline Age & & $(0.1446)$ & & $(0.1446)$ \\
\hline 2000 Recession x Early & & -0.1280 & & -0.1272 \\
\hline Retirement & & $(0.1017)$ & & $(0.1018)$ \\
\hline 2000 Recession x Normal & & 0.0217 & & 0.0323 \\
\hline Retirement & & $(0.1273)$ & & $(0.1274)$ \\
\hline \multirow[t]{2}{*}{ Expansion x Preretirement Age } & & -0.2448 & & -0.2312 \\
\hline & & $(0.1541)$ & & $(0.1542)$ \\
\hline \multirow[t]{2}{*}{ Expansion x Early Retirement } & & -0.4020 & & -0.4011 \\
\hline & & $(0.0959)$ & & $(0.0959)$ \\
\hline \multirow[t]{2}{*}{ Expansion x Normal Retirement } & & 0.1123 & & 0.1069 \\
\hline & & $(0.1569)$ & & $(0.1571)$ \\
\hline 2008 Recession x Preretirement & & -0.5227 & & -0.5289 \\
\hline Age & & $(0.4134)$ & & $(0.4143)$ \\
\hline 2008 Recession x Early & & -1.5626 & & -1.5540 \\
\hline Retirement & & $(0.3382)$ & & $(0.3382)$ \\
\hline 2008 Recession x Normal & & -1.4146 & & -1.4095 \\
\hline Retirement & & $(0.4846)$ & & $(0.4847)$ \\
\hline
\end{tabular}


Table 9.

Complementary Log-Log Regression

Home Equity and Financial Splines

(cont'd)

\begin{tabular}{|c|c|c|c|c|}
\hline Variable & Model 1 & Model 2 & Model 3 & Model 4 \\
\hline \multicolumn{5}{|l|}{ Age Indicators } \\
\hline \multirow[t]{2}{*}{ Age 59} & -2.6879 & -2.7137 & -2.7957 & -2.8209 \\
\hline & $(0.1505)$ & $(0.1532)$ & $(0.1543)$ & $(0.1570)$ \\
\hline \multirow[t]{2}{*}{ Age 60} & -2.3415 & -2.3725 & -2.4486 & -2.4792 \\
\hline & $(0.1433)$ & $(0.1475)$ & $(0.1473)$ & $(0.1514)$ \\
\hline \multirow[t]{2}{*}{ Age 61} & -2.1664 & -2.1989 & -2.2771 & -2.3093 \\
\hline & $(0.1420)$ & $(0.1474)$ & $(0.1462)$ & $(0.1515)$ \\
\hline \multirow[t]{2}{*}{ Age 62} & -1.0095 & -0.9858 & -1.1190 & -1.0936 \\
\hline & $(0.1234)$ & $(0.1260)$ & $(0.1281)$ & $(0.1305)$ \\
\hline \multirow[t]{2}{*}{ Age 63} & -1.2904 & -1.2641 & -1.3997 & -1.3716 \\
\hline & $(0.1346)$ & $(0.1375)$ & $(0.1389)$ & $(0.1417)$ \\
\hline \multirow[t]{2}{*}{ Age 64} & -1.4846 & -1.4493 & -1.5876 & -1.5475 \\
\hline & $(0.1482)$ & $(0.1514)$ & $(0.1517)$ & $(0.1546)$ \\
\hline \multirow[t]{2}{*}{ Age 65} & -1.0251 & -1.1190 & -1.1281 & -1.2193 \\
\hline & $(0.1441)$ & $(0.1504)$ & $(0.1476)$ & $(0.1537)$ \\
\hline \multirow[t]{2}{*}{ Age 66} & -0.9796 & -1.2591 & -1.0814 & -1.3568 \\
\hline & (0.1559) & $(0.2056)$ & $(0.1592)$ & $(0.2081)$ \\
\hline \multirow[t]{2}{*}{ Age 67} & -1.5521 & -1.7799 & -1.6599 & -1.8847 \\
\hline & $(0.2015)$ & $(0.2538)$ & $(0.2044)$ & $(0.2561)$ \\
\hline \multirow[t]{2}{*}{ Age 68} & -1.7055 & -1.9845 & -1.8157 & -2.0905 \\
\hline & $(0.2415)$ & $(0.2987)$ & $(0.2442)$ & $(0.3008)$ \\
\hline \multirow[t]{2}{*}{ Age 69} & -1.6779 & -1.9852 & -1.7863 & -2.0927 \\
\hline & $(0.2696)$ & $(0.3259)$ & $(0.2717)$ & $(0.3276)$ \\
\hline \multirow[t]{2}{*}{ Age 70} & -1.9321 & -2.1557 & -2.0512 & -2.2757 \\
\hline & $(0.3385)$ & $(0.3906)$ & $(0.3407)$ & $(0.3925)$ \\
\hline \multirow[t]{2}{*}{ Age 71-76 } & -1.9527 & -2.3354 & -2.0653 & -2.4497 \\
\hline & $(0.2671)$ & $(0.3138)$ & $(0.2694)$ & $(0.3159)$ \\
\hline \multirow[t]{2}{*}{ Age 71-76 } & -1.9328 & -2.3446 & -1.7511 & -2.1480 \\
\hline & $(0.3387)$ & $(0.3781)$ & $(0.2624)$ & $(0.3097)$ \\
\hline Log-Likelihood & -3630.26 & -3603.98 & -3624.71 & -3698.57 \\
\hline
\end{tabular}


Table 10.

Complementary Log-Log Regression

Revised Estimates

\begin{tabular}{|c|c|c|c|c|}
\hline Variable & $\begin{array}{c}\text { New } \\
\text { Estimates } \\
\text { Model 7-3 } \\
\end{array}$ & $\begin{array}{c}\text { New } \\
\text { Estimates } \\
\text { Model 7-4 } \\
\end{array}$ & $\begin{array}{c}\text { New } \\
\text { Estimates } \\
\text { Model 9-3 } \\
\end{array}$ & $\begin{array}{c}\text { New } \\
\text { Estimates } \\
\text { Model 9-4 } \\
\end{array}$ \\
\hline \multicolumn{5}{|l|}{ Demographic Variables } \\
\hline Black & $\begin{array}{r}-0.00511 \\
(0.0993)\end{array}$ & $\begin{array}{r}-0.0187 \\
(0.0993)\end{array}$ & $\begin{array}{r}0.00776 \\
(0.0996)\end{array}$ & $\begin{array}{r}-0.00864 \\
(0.0996)\end{array}$ \\
\hline Other Race & $\begin{array}{r}0.0461 \\
(0.1769)\end{array}$ & $\begin{array}{r}0.0509 \\
(0.1770)\end{array}$ & $\begin{array}{r}0.0244 \\
(0.1761)\end{array}$ & $\begin{array}{r}0.0225 \\
(0.1762)\end{array}$ \\
\hline College & $\begin{array}{r}-0.3357 \\
(0.0718)\end{array}$ & $\begin{array}{r}-0.3244 \\
(0.0720)\end{array}$ & $\begin{array}{r}-0.3263 \\
(0.0720)\end{array}$ & $\begin{array}{r}-0.3209 \\
(0.0721)\end{array}$ \\
\hline Health Very Good & $\begin{array}{r}-0.1586 \\
(0.0584)\end{array}$ & $\begin{array}{r}-0.1686 \\
(0.0585)\end{array}$ & $\begin{array}{r}-0.1602 \\
(0.0585)\end{array}$ & $\begin{array}{r}-0.1696 \\
(0.0586)\end{array}$ \\
\hline Spouse Disabled & $\begin{array}{r}0.1095 \\
(0.1055)\end{array}$ & $\begin{array}{r}0.1201 \\
(0.1058)\end{array}$ & $\begin{array}{r}0.1066 \\
(0.1055)\end{array}$ & $\begin{array}{r}0.1184 \\
(0.1058)\end{array}$ \\
\hline Spouse Retired & $\begin{array}{r}0.0990 \\
(0.0917)\end{array}$ & $\begin{array}{r}0.0968 \\
(0.0919)\end{array}$ & $\begin{array}{r}0.0944 \\
(0.0916)\end{array}$ & $\begin{array}{r}0.0955 \\
(0.0917)\end{array}$ \\
\hline Spouse Homemaker & $\begin{array}{r}-0.2029 \\
(0.0821)\end{array}$ & $\begin{array}{r}-0.2073 \\
(0.0826)\end{array}$ & $\begin{array}{r}-0.1963 \\
(0.0821)\end{array}$ & $\begin{array}{r}-0.1979 \\
(0.0825)\end{array}$ \\
\hline Spouse Homemaker x Years Off & $\begin{array}{r}-0.0649 \\
(0.0378)\end{array}$ & $\begin{array}{r}-0.0566 \\
(0.0410)\end{array}$ & $\begin{array}{r}-0.0616 \\
(0.0379)\end{array}$ & $\begin{array}{r}-0.0552 \\
(0.0410)\end{array}$ \\
\hline \multicolumn{5}{|l|}{ Workplace Variables } \\
\hline Log Spouse Income & $\begin{array}{r}-0.0302 \\
(0.00743)\end{array}$ & $\begin{array}{r}-0.0304 \\
(0.00746)\end{array}$ & $\begin{array}{r}-0.0310 \\
(0.00743)\end{array}$ & $\begin{array}{r}-0.0309 \\
(0.00744)\end{array}$ \\
\hline Log Own Income & $\begin{array}{r}-0.0674 \\
(0.00729)\end{array}$ & $\begin{array}{r}-0.0659 \\
(0.00729)\end{array}$ & $\begin{array}{r}-0.0671 \\
(0.00729)\end{array}$ & $\begin{array}{r}-0.0657 \\
(0.00729)\end{array}$ \\
\hline Defined Benefit Plan & $\begin{array}{r}1.1159 \\
(0.0829)\end{array}$ & $\begin{array}{r}1.1064 \\
(0.0826)\end{array}$ & $\begin{array}{r}1.1092 \\
(0.0829)\end{array}$ & $\begin{array}{r}1.1031 \\
(0.0826)\end{array}$ \\
\hline Defined Contribution Plan & $\begin{array}{r}0.5717 \\
(0.0793)\end{array}$ & $\begin{array}{r}0.5561 \\
(0.0791)\end{array}$ & $\begin{array}{r}0.5717 \\
(0.0792)\end{array}$ & $\begin{array}{r}0.5573 \\
(0.0791)\end{array}$ \\
\hline \multicolumn{5}{|l|}{ Housing Variables } \\
\hline Log Home Value & $\begin{array}{r}0.0285 \\
(0.0109)\end{array}$ & $\begin{array}{r}0.0298 \\
(0.0110)\end{array}$ & & \\
\hline Home Equity Spline Part 1 & & & $\begin{array}{r}2.5852 \\
(0.9473)\end{array}$ & $\begin{array}{r}2.1277 \\
(0.9579)\end{array}$ \\
\hline Home Equity Spline Part 2 & & & $\begin{array}{r}-0.5577 \\
(0.2381)\end{array}$ & $\begin{array}{r}-0.4177 \\
(0.2338)\end{array}$ \\
\hline Log Mortgage & $\begin{array}{r}-0.0232 \\
(0.00581)\end{array}$ & $\begin{array}{r}-0.0229 \\
(0.00582)\end{array}$ & $\begin{array}{r}-0.0175 \\
(0.00546)\end{array}$ & $\begin{array}{r}-0.0171 \\
(0.00546)\end{array}$ \\
\hline
\end{tabular}

Financial Variables

Financial Assets

Financial Assets Spline Part 1

\begin{tabular}{rrrr}
2.5207 & 2.1358 & 2.5725 & 2.3139 \\
$(0.7935)$ & $(0.7954)$ & $(0.8116)$ & $(0.8133)$ \\
-0.1991 & -0.1906 & -0.1490 & -0.1501 \\
$(0.0516)$ & $(0.0509)$ & $(0.0509)$ & $(0.0510)$ \\
\hline
\end{tabular}


Table 10

Complementary Log-Log Regression

Revised Estimates

(cont'd)

\begin{tabular}{|c|c|c|c|c|}
\hline Variable & $\begin{array}{c}\text { New } \\
\text { Estimates } \\
\text { Model 7-3 }\end{array}$ & $\begin{array}{c}\text { New } \\
\text { Estimates } \\
\text { Model 7-4 } \\
\end{array}$ & $\begin{array}{c}\text { New } \\
\text { Estimates } \\
\text { Model 9-3 }\end{array}$ & $\begin{array}{c}\text { New } \\
\text { Estimates } \\
\text { Model 9-4 } \\
\end{array}$ \\
\hline \multicolumn{5}{|l|}{ Post - 1999 Variables } \\
\hline Post - 1999 Indicator & $\begin{array}{r}-0.2931 \\
(0.0622)\end{array}$ & & $\begin{array}{r}-0.2703 \\
(0.0627)\end{array}$ & \\
\hline 2000 Recession x Preretirement Age & & $\begin{array}{r}-0.1332 \\
(0.1446)\end{array}$ & & $\begin{array}{r}-0.1276 \\
(0.1018)\end{array}$ \\
\hline 2000 Recession x Early Retirement & & $\begin{array}{r}-0.1341 \\
(0.1017)\end{array}$ & & $\begin{array}{r}0.0315 \\
(0.1274)\end{array}$ \\
\hline 2000 Recession x Normal & & 0.0348 & & -0.2327 \\
\hline Retirement & & $(0.1272)$ & & $(0.1542)$ \\
\hline Expansion x Preretirement Age & & $\begin{array}{r}-0.2456 \\
(0.1537)\end{array}$ & & $\begin{array}{r}-0.4016 \\
(0.0959)\end{array}$ \\
\hline Expansion x Early Retirement & & $\begin{array}{r}-0.4236 \\
(0.0952)\end{array}$ & & $\begin{array}{r}0.0989 \\
(0.1573)\end{array}$ \\
\hline Expansion x Normal Retirement & & $\begin{array}{r}0.0856 \\
(0.1572)\end{array}$ & & $\begin{array}{r}-0.4506 \\
(0.4146)\end{array}$ \\
\hline 2008 Recession x Preretirement Age & & $\begin{array}{r}-0.5024 \\
(0.4145)\end{array}$ & & $\begin{array}{r}-1.4578 \\
(0.3389)\end{array}$ \\
\hline 2008 Recession x Early Retirement & & $\begin{array}{r}-1.5359 \\
(0.3383)\end{array}$ & & $\begin{array}{r}-1.3181 \\
(0.4855)\end{array}$ \\
\hline $\begin{array}{l}2008 \text { Recession x Normal } \\
\text { Retirement }\end{array}$ & & $\begin{array}{l}-1.3997 \\
(0.4851)\end{array}$ & & $\begin{array}{r}-2.8212 \\
(0.1569)\end{array}$ \\
\hline
\end{tabular}


Table 10

Complementary Log-Log Regression

Revised Estimates

(cont'd)

\begin{tabular}{|c|c|c|c|c|}
\hline Variable & $\begin{array}{c}\text { New } \\
\text { Estimates } \\
\text { Model 7-3 } \\
\end{array}$ & $\begin{array}{c}\text { New } \\
\text { Estimates } \\
\text { Model 7-4 } \\
\end{array}$ & $\begin{array}{c}\text { New } \\
\text { Estimates } \\
\text { Model 9-3 } \\
\end{array}$ & $\begin{array}{c}\text { New } \\
\text { Estimates } \\
\text { Model 9-4 } \\
\end{array}$ \\
\hline \multicolumn{5}{|l|}{ Age Indicators } \\
\hline \multirow[t]{2}{*}{ Age 59} & -2.9476 & -2.9646 & -2.8369 & -2.8212 \\
\hline & $(0.1734)$ & $(0.1762)$ & $(0.1544)$ & (0.1569) \\
\hline \multirow[t]{2}{*}{ Age 60} & -2.6026 & -2.6254 & -2.4910 & -2.4801 \\
\hline & $(0.1676)$ & $(0.1716)$ & $(0.1475)$ & (0.1513) \\
\hline \multirow[t]{2}{*}{ Age 61} & -2.4300 & -2.4549 & -2.3181 & -2.3095 \\
\hline & $(0.1665)$ & $(0.1716)$ & $(0.1463)$ & $(0.1514)$ \\
\hline \multirow[t]{2}{*}{ Age 62} & -1.2680 & -1.2336 & -1.1574 & -1.0938 \\
\hline & $(0.1503)$ & $(0.1527)$ & $(0.1281)$ & $(0.1304)$ \\
\hline \multirow[t]{2}{*}{ Age 63} & -1.5506 & -1.5113 & -1.4420 & -1.3727 \\
\hline & $(0.1595)$ & $(0.1621)$ & $(0.1391)$ & $(0.1417)$ \\
\hline \multirow[t]{2}{*}{ Age 64} & -1.7407 & -1.6909 & -1.6287 & -1.5491 \\
\hline & $(0.1711)$ & $(0.1739)$ & $(0.1516)$ & $(0.1545)$ \\
\hline \multirow{2}{*}{ Age 65} & -1.2802 & -1.3633 & -1.1684 & -1.2188 \\
\hline & $(0.1675)$ & $(0.1729)$ & $(0.1477)$ & $(0.1535)$ \\
\hline \multirow[t]{2}{*}{ Age 66} & -1.2371 & -1.4981 & -1.1201 & -1.3511 \\
\hline & $(0.1780)$ & $(0.2225)$ & $(0.1593)$ & $(0.2078)$ \\
\hline \multirow[t]{2}{*}{ Age 67} & -1.8086 & -2.0234 & -1.6874 & -1.8776 \\
\hline & $(0.2188)$ & $(0.2676)$ & $(0.2040)$ & $(0.2558)$ \\
\hline \multirow[t]{2}{*}{ Age 68} & -1.9722 & -2.2282 & -1.8510 & -2.0844 \\
\hline & $(0.2566)$ & $(0.3105)$ & $(0.2439)$ & $(0.3006)$ \\
\hline \multirow[t]{2}{*}{ Age 69} & -1.9372 & -2.2360 & -1.8173 & -2.0843 \\
\hline & $(0.2833)$ & $(0.3370)$ & $(0.2718)$ & $(0.3275)$ \\
\hline \multirow[t]{2}{*}{ Age 70} & -2.2010 & -2.4168 & -2.0749 & -2.2669 \\
\hline & $(0.3497)$ & $(0.4000)$ & $(0.3403)$ & $(0.3924)$ \\
\hline \multirow[t]{2}{*}{ Age $71-76$} & -2.2343 & -2.6081 & -2.0873 & -2.4205 \\
\hline & $(0.2816)$ & $(0.3262)$ & $(0.2691)$ & $(0.3161)$ \\
\hline Log-Likelihood & -3623.53 & -3698.37 & -3620.45 & -3698.27 \\
\hline
\end{tabular}


Figure 1

Actual and Predicted Retirement Rates by Year

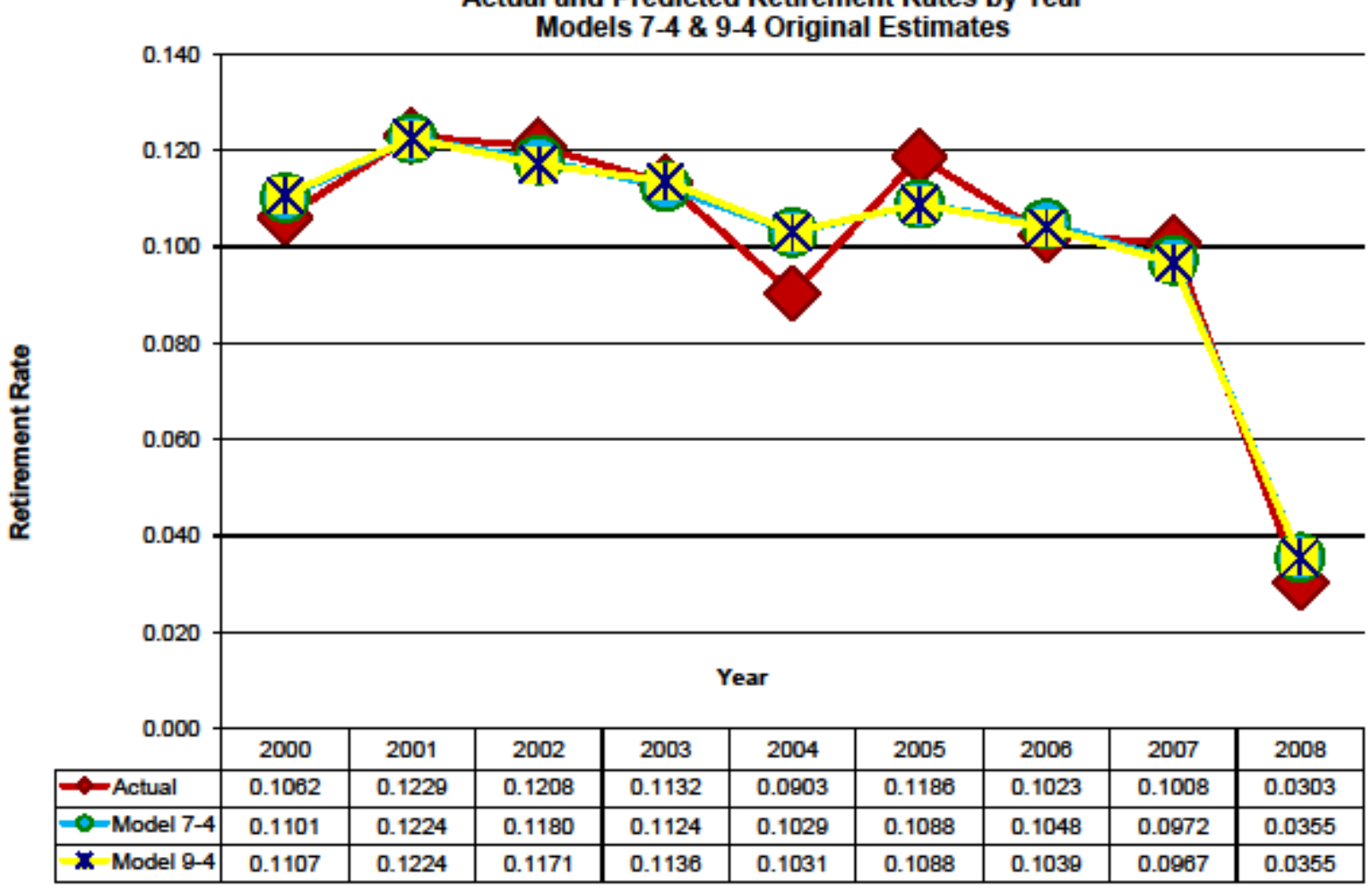


Figure 2

Actual and Predicted Retirement Rates by Year

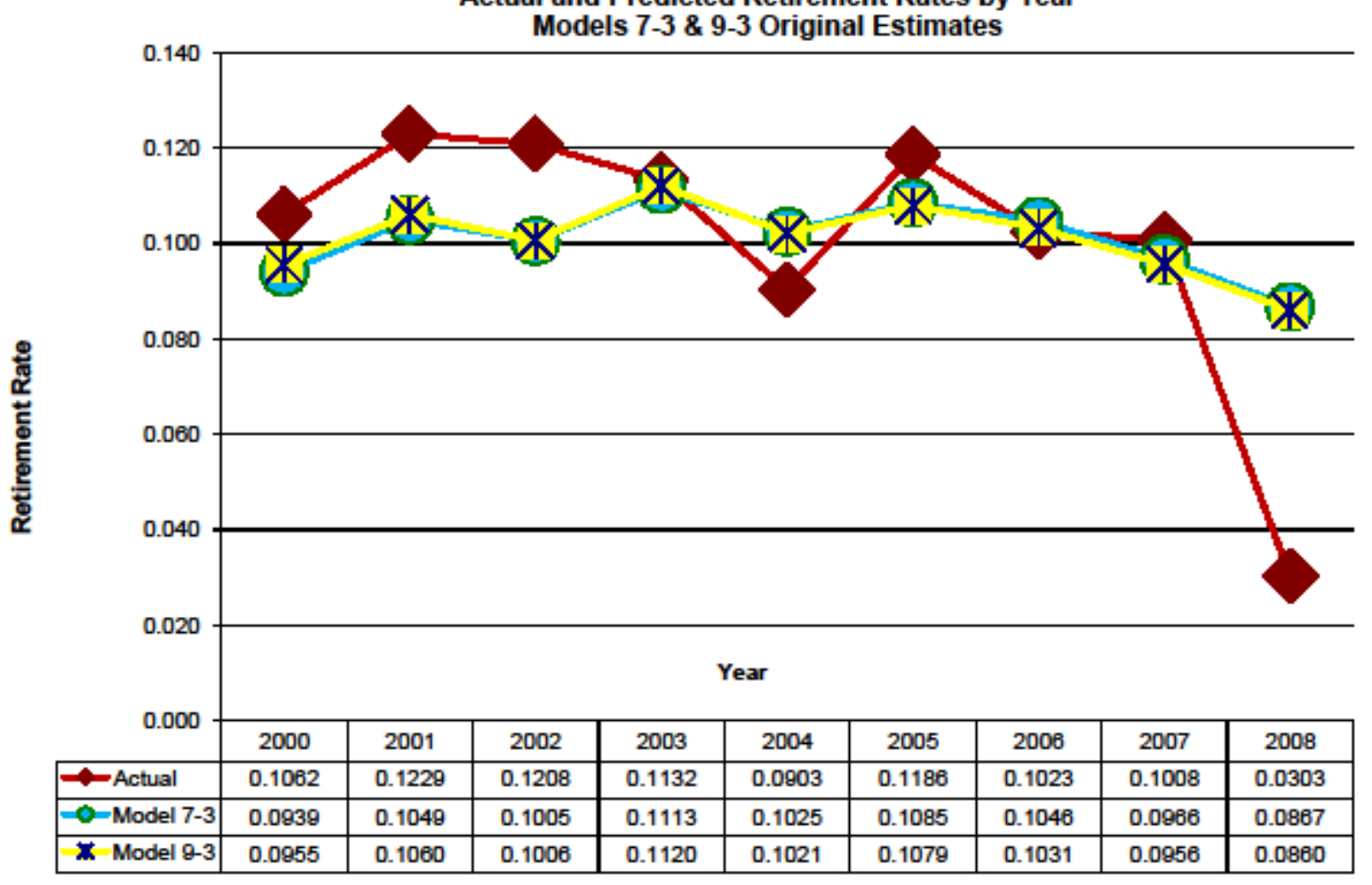


Figure 3

Actual and Predicted Retirement Rates by Year Models 7-4 \& 9-4 Revised Estimates

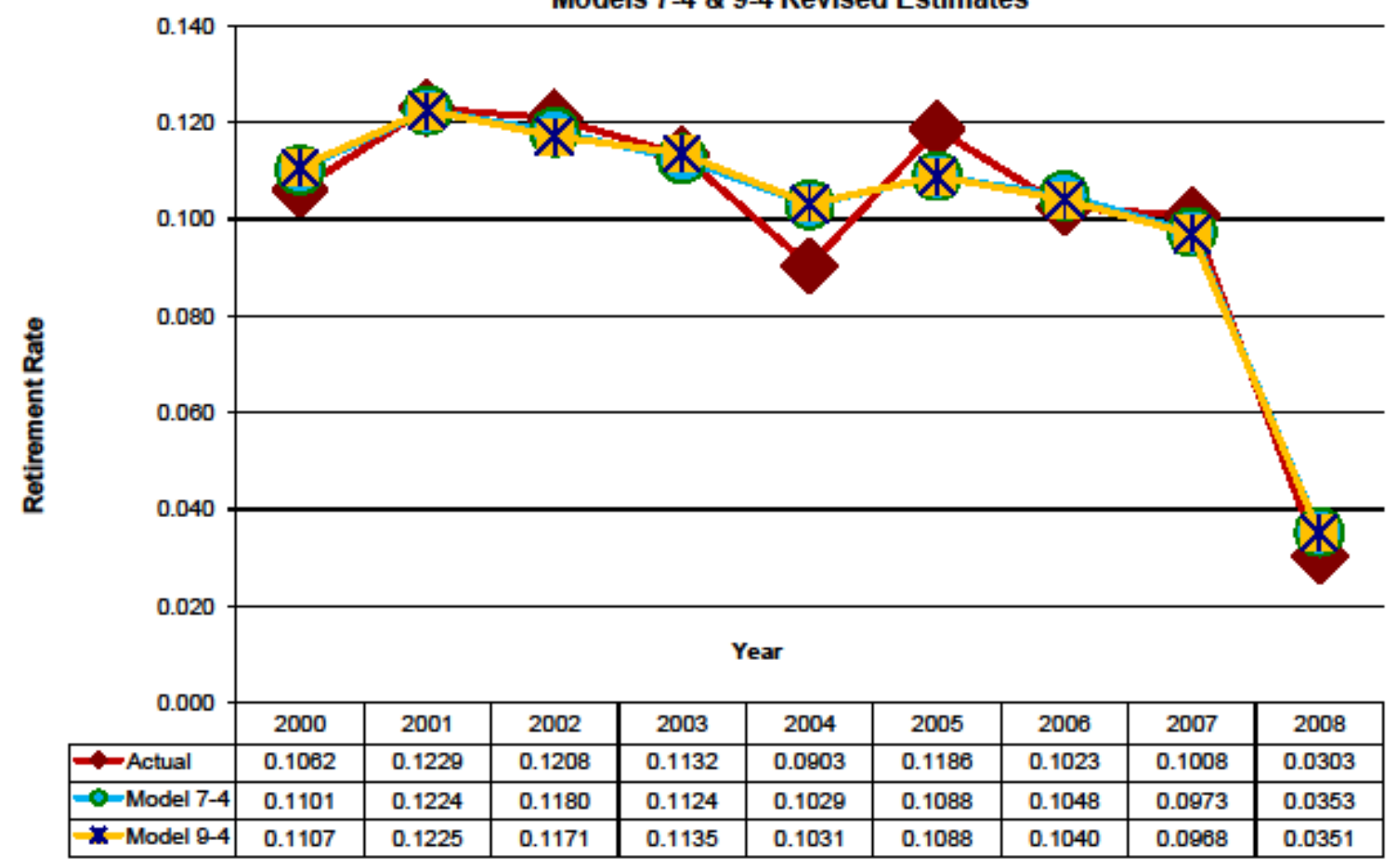


Figure 4

Actual and Predicted Retirement Rates by Year Models 7-3 \& 9-3 Revised Estimates

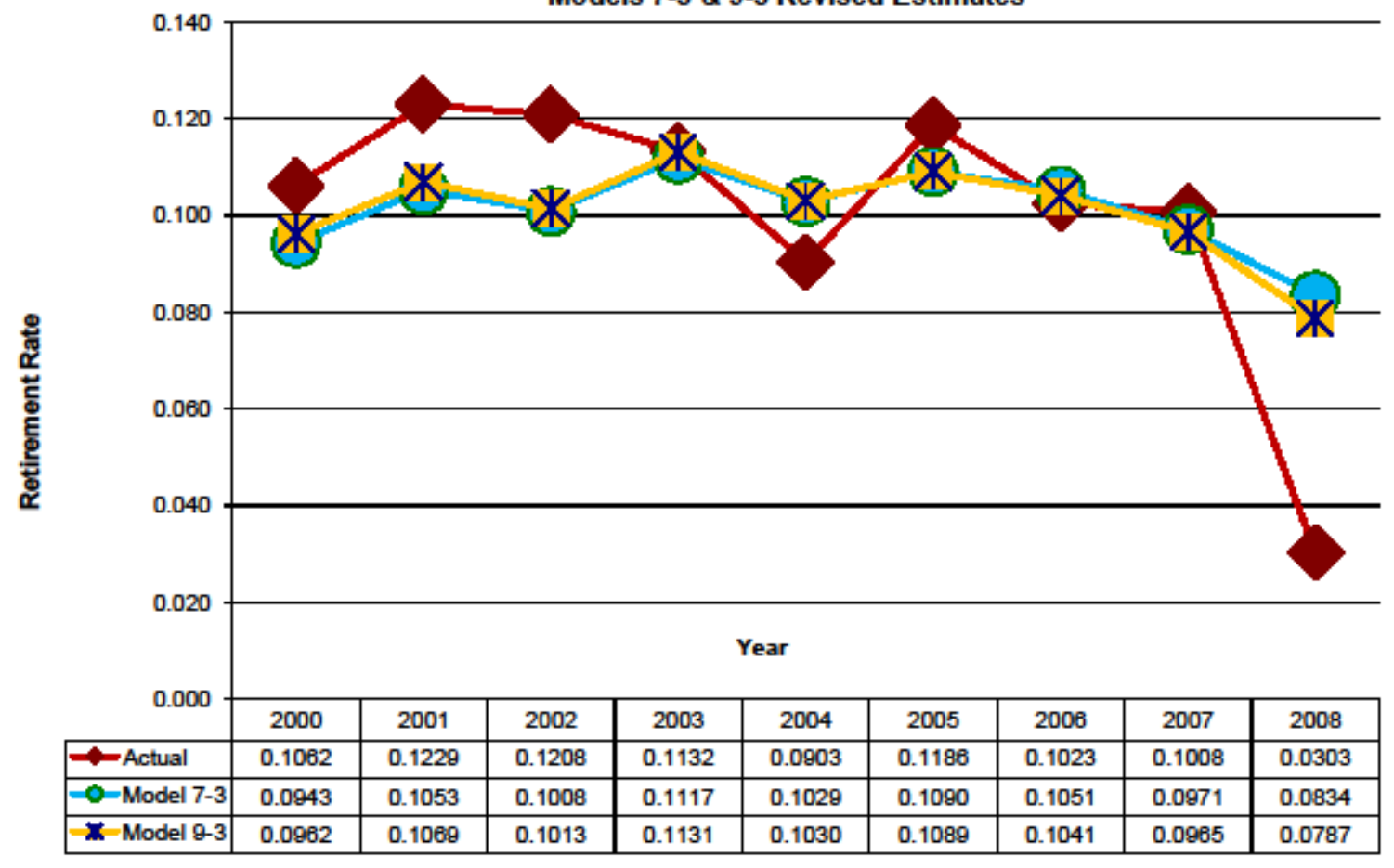




\section{RECENT WORKING PAPERS FROM THE}

\section{CENTER FOR RETIREMENT RESEARCH AT BOSTON COLLEGE}

Housing Consumption in Late Life: The Role of Income, Health Shocks, and Marital Shocks Douglas A. Wolf and Janet M. Wilmoth, September 2010

Adjusting Social Security for Increasing Life Expectancy: Effects on Progressivity

Courtney Monk, John A. Turner, and Natalia A. Zhivan, August 2010

Work and Retirement Patterns for the G.I. Generation, Silent Generation, and Early Boomers: Thirty Years of Change

Richard W. Johnson, Barbara A. Butrica, and Corina Mommaerts, July 2010

Spousal Health Shocks and the Timing of the Retirement Decision in the Face of ForwardLooking Financial Incentives

Courtney Harold Van Houtven and Norma B. Coe, June 2010

Incorporating Employee Heterogenity Into Default Rules for Retirement Plan Selection Gopi Shah Godi and Colleen Flaherty Manchester, May 2010

Accurately Measuring Health Over the Life Course

Fabian Lange and Doug McKee, May 2010

Getting to the Top of Mind: How Reminders Increase Saving

Dean Karlan, Margaret McConnell, Sendhil Mullainathan, and Jonathan Zinman, April 2010

The Shrinking Tax Preference for Pension Savings: An Analysis of Income Tax Changes, 1985-2007

Gary Burtless and Eric Toder, March 2010

Social Security, Benefit Claiming and Labor Force Participation: A Quantitative General Equilibrium Approach

Selahattin İmrohoroğlu and Sagiri Kitao, March 2010

How Much Is Enough? The Distribution of Lifetime Health Care Costs

Anthony Webb and Natalia Zhivan, February 2010

Impact of Immigration on the Distribution of American Well-Being

Gary Burtless, December 2009

Actual and Anticipated Inheritance Receipts

Norma B. Coe and Anthony Webb, December 2009

Will Automatic Enrollment Reduce Employer Contributions to 401(k) Plans

Mauricio Soto and Barbara A. Butrica, December 2009

All working papers are available on the Center for Retirement Research website

(http://crr.bc.edu) and can be requested by e-mail (crr@bc.edu) or phone (617-552-1762). 